\title{
Omkring genforeningen
}

\section{Erindringsbilleder}

\author{
Ved P. Engelbrechtsen.
}

\section{Blodets bånd.}

Min hensigt er ikke at give nogen levnedsskildring. Min egen person spiller kun øjenvidnets rolle, men det må dog være rigtigt at anføre nogle oplysninger, som kan begrunde min optagethed af emnet.

Min lærer $i$ oldtidskundskab til studentereksamen skildrede engang Akropolis så betagende, at vi lyttede $\mathrm{i}$ åndeløs stilhed, indtil én af kammeraterne profanerede det hele ved at spørge: $₫ \mathrm{Har} \mathrm{De}$ været der, hr. Steen? « - Hr. Steen stoppede på sin traditionelle vandring, snappede efter vejret og sagde: »Ja!! - Men tak, fordi De spurgte!« Han var engageret; derfor havde han været der. Med en lille omskrivning kan jeg sige: »Jeg var engageret - derfor kom jeg der!«

Blodet fornægter sig ikke. Min farfader ejede en lille gård $i$ Vimtrup i Lintrup sogn. Der var en pige og tre drenge i hjemmet. Min fader var den yngste i flokken, født 1863. Efterhånden, som drengene nåede det attende år, valgte de at udvandre til Danmark og aftjene deres værnepligt dér fremfor at trække $i$ den tyske uniform. Som optanter var de forment adgang til hjemstavnen, og det føltes så meget mere smerteligt, som moderen tidlig blev enke og havde vanskeligt ved at få gården passet, særlig i høsttiden. De tre brødre boede alle $\mathrm{i}$ Vejen lige nord for grænsen og præsterede gang på gang at vade gennem Kongeåen natten mellem lordag og søndag for $\mathrm{i}$ al hemmelighed at arbejde på gården. Der måtte hele tiden holdes udkig efter den ridende gendarm, for hvem det både var en pligt og en sport at arrestere optanter. Det gøs $\mathrm{i}$ mig, når jeg som dreng hørte min farbror Niels berette, hvordan han en 
sommersøndag fik øje på gendarmen, som pludselig i fuld fart satte over markerne ned mod gården. Det lykkedes farbror at smutte ind i laden uden at blive set, at springe op fra logulvet og hæve sig op på kornloftet, et kunststykke, han aldrig før havde kunnet udføre.

Gendarmen var redet ind på gårdspladsen og holdt forhør over min farmor, men hun var vant til forholdene og lod sig ikke bringe ud af fatning. Hun røbede intet, og gendarmen »tog da sagen $i$ egen hånd «: han undersøgte udhusene, også laden. Her stak han sin lange sabel ind i negene på kornloftet, heldigvis uden at ramme »forbryderen «, der havde boret sig et godt stykke ind i den skærmende afgrøde.

Også på min moders side var der bånd sydpå. Min morfader, gårdejer Svend Christiansen Engelbrecht, Vejen, var indkaldt $\mathrm{i}$ 1848-51, og hans krigsmedalje er i slægtens eje. Han døde, før jeg blev født, men adskillige af de 23, som var med fra Vejen, kom stadig i mit hjem. De opfandt godt og fortalte livligt. En af dem var nu postbud. Han var blevet såret. En kugle slyngede et stykke træ op $\mathrm{i}$ hans pande. Når han nu på sin postrute tørrede sveden af panden, lyste arret langt, bredt og rødt og fremkaldte en vis ærefrygt hos beskueren. Trans havde jo »været i krig!«

På nabogården, »Taborgård «, boede Pihlkjær, gift med Sine, som på grund af sit giftermål med nordjyden Pihlkjær havde måttet forlade sin arvede gård, »Ganderupgård «, i Fole sogn. De var vågne og nationalt bevidste mennesker. Enhver begivenhed »sønden å blev drøftet mellem naboerne, naturligvis især valgene, og navne som H. P. Hanssen-Nørremølle, Kloppenborg Skrumsager og Nis Nissen var bestandig på tale. J. N. H. Skrumsagers kampestenshus »Frihed «, som ligger på Kongeåens nordside, og som husede Skrumsager, når han fandt det tilrådeligt for en tid at lxgge afstand mellem sig og de tyske myndigheder, stod for os drenge som danskhedens faste borg.

Det var en given sag, at slægt og venner nordfra skulle besøge Kongeåen og Skibelund krat, og min drengedrøm var, at den danske konge skulle ride over Kongebroen ved Skodborghus og genvinde Sønderjylland. Det er derfor forståeligt, at vi fandt det oprørende, at kong Frederik den Ottende under sit besøg i Vejen og Askov 1908 ikke måtte besøge Skibelund, der rummede Hansen-Jacobsens "Modersmålet« og Niels Skovgaards "Magnusstenen«, og som var 
den nationale samlingsplads. At det så sivede ud, at kongen en tidlig morgenstund $\mathrm{i}$ al hemmelighed sammen med sin adjudant forlod sit natkvarter hos nationalbankdirektør Johannes Lauridsen, "Grønvang«, og fra Skibelund bakker så ud over Sønderjylland og bagefter sagde "godmorgen" til sine værtsfolk omtrent som H. C. Andersens kineserkejser, bødede noget på harmen.

Dengang kunne ellers mere almindelige mennesker uhindret passere grænsen, og vi aflagde ikke sjældent besøg hos slægtninge forskellige steder i Sønderjylland, bl. a. i Haderslev, hvor naturligvis den store kaserne og ikke mindre de tyske soldater, som under kommando stramt marcherede til gudstjeneste i Mariekirken, nu Frue Kirke, imponerede os. Dette er nogle af mine tilknytningspunkter til Sønderjylland, og jeg kan ikke lade være at udtrykke min taknemmelighed over, at de tre brødre fra Vimtrup og Pihlkjær fra Fole fik lov til sammen at køre over åen og afgive deres stemme 10. februar 1920.

\section{Pilen peger mod syd.}

I vinteren 1918-19 var jeg lærer ved Skibelund efterskole. Den var en grænse-efterskole, hvor store drenge fra danske hjem i Sønderjylland mødtes med elever fra kongeriget. Nogle af "drengene" var dette år temmelig store, den ældste 20 år. Han havde været tysk soldat, men var gået over grænsen. En af skolens faste lærere, Niels Kjems, nu Harreslev, »kom hjem« lige før jul. Han lå på Vestfronten og gik efter våbenstilstanden østpå, »fandt « en motorcykel, kørte, så langt benzin var at finde, "tog derefter sammen med en kammerat et par heste og red til Hamborg «. Han var ikke mere medtaget af krigsårene, end at han straks efter jul tog til Bukh i Ollerup for at få det nyeste på gymnastikkens område med, inden han overtog gymnastikken på efterskolen. Hans eksempel kan tages som et udtryk for den uforknytte tone, der var på skolen.

Vinterskolen begyndte den historiske dag 11. i 11. 1918. Det første, som skete, var flaghejsningen. Flagstangen havde været taget ned under krigen. Nu blev den rejst, og den gæve gamle forstander Knud Pedersen stod med en passende hammer fra sløjdsalen, parat til at hamre bolten $i$, når tid var!

Indendørs var der også et flag. Det skulle hejses syd for den 
gamle grænse, når genforeningen kom! Under det og et billede af den gamle barde Morten Eskesen var indsat et vers af Bjørnson:

\author{
Hvor Danmarks jord blev revet over, \\ så hjerterødderne hang ved, \\ did Morten Eskesen sig vover \\ med trofast trost fra sted til sted. \\ Han vil med sine tusind' fjed \\ sy sammen, hrad de søndersled.
}

Morten Eskesen døde 1913, men hans indsats levede stadig i sønderjyske kredse.

Genforeningshåbet var det bærende $i$ hele vinterens arbejde, skønt en genforening naturligvis helt kunne andre skolens forhold. Denne uselviskhed både hos det gamle forstanderpar Knud og Georgia la Cour Pedersen og hos de unge forstandere Kristian og Marie la Cour Pedersen gjorde stærkt indtryk på mig.

»Den spanske syge« huserede slemt på skolen. Gymnastiksalen var $\mathrm{i}$ lang tid sygestue, og meget af min tid gik med at kontrollere temperatur og rede sygesenge. Flere elever var hårdt angrebet, men lykkeligvis døde ingen. Sygdommen medførte, at ikke få forældre fik tilladelse til at komme over grænsen på besøg, og dette forte til gode samtaler i dagligstuen.

Tiden gik, uden at den forventede grænseflytning gennem en afstemning fandt sted. I oktober 1919 fik jeg indkaldelsesordre til militærtjeneste. Jeg havde om sommeren været ansat ved en børneskole i sognet og cyklede nu ned til efterskolen for at tage afsked, inden jeg skulle møde på Sølvgades kaserne i København. Kristian la Cour og jeg fik en hyggelig passiar, men pludselig siger han: *Hør, kan du ikke give mig anvisning på en dygtig lærer? Jeg har fået brev fra Haderslev. Der er en privat kreds, som starter en privatskole, og nu skriver de til mig og beder mig skaffe dem en dygtig lærer «.

"Jo, det kunne jeg måske nok ", og jeg nævnede et par af mine bekendte, som var ledige. la Cour viste mig brevet, som var underskrevet af Sorgenfri, bestyrelsens sekretær: „... ren dansk skole som afhjxelpelse på de dårlige skoleforhold ... Lokaler havde de lovning på ... Lønnen var 400 mark mdl.«.

$\mathrm{Vi}$ talte lidt nøjere om tingene, og jeg siger: "Jeg kunne i grunden have knusende lyst til selv at komme derned!« 
"Ja, det er da også dumt, at du skal være soldat. Kan du ikke blive fri eller søge udsættelse? «

»Det bliver vist vanskeligt. Min indkaldelsesordre er kommet jeg skal møde 25. oktober .

"Jamen skynd dig alligevel og send en ansøgning. Jeg skal attestere, at der hos mig ligger en opfordring til dig fra Haderslev. Er denne her ikke til dig personlig, skal jeg skaffe den, og jeg skal også give dig en anbefaling, så de tager dig i Haderslev. Du skal absolut derned. Det er sandelig mere værd end at ligge som soldat $i$ Kobenhavn *.

Jeg blev grebet af forstanderens iver. Hjem, lavede en ansøgning til krigsminister Munk, fik den attesteret og sendt.

Så gik jeg og ventede $i$ angst og spæending. Skolen i Haderslev skulle begynde 20 . oktober. 21. - 22. - 23. Intet resultat! Jeg drog til København og Sølvgades kaserne - og fik her besked på, at ministeriet havde tilstået mig to års udsættelse! Glad var jeg og ilede hjem for at få mit pas $\mathrm{i}$ orden. Ganske vist havde jeg tre gange været syd for grænsen, illegalt. Den ene gang med et døgns ufrivilligt ophold i Rodding arrest som "grænseoverløber", men denne gang gjaldt det jo et varigt ophold $\mathrm{i}$ landsdelen. Vente på visering af passet kunne jeg ikke, da den 20. jo var overskredet, så jeg benyttede et gammelt kneb. Jeg gik ind $i$ den tyske vagt ved Kongeåbroen og spurgte, om jeg måtte køre en tur til Skodborg. "Jeg skal nok være tilbage inden klokken 5 «, tilføjede jeg. Et nik $\mathrm{og}$ en håndbevæegelse, $\mathrm{og} \mathrm{jeg}$ cyklede til Haderslev.

Jeg fandt frem til snedkermester Sorgenfri i Gåskærgade. "Det er vist en heldig stund, De er kommet $i$ «, sagde han. "Der er for mange børn til én lærer, så vi har talt om at antage én til!»

Ser man det! Der var altså antaget en lærer! Militærvæsenet havde altså sinket mig så meget, at jeg i virkeligheden var kommet for sent. Men chancen var der altså alligevel.

»Jeg er til tjeneste straks «, sagde jeg. Vi talte derefter bl.a. om Skibelund efterskole, hvor en søn af Sorgenfri var elev.

- Ja, Neergaard kommer her i morgen eftermiddag. Har De lyst, så kom herom. Jeg sammenkalder så bestyrelsen til mandag aften her «.

Søndag eftermiddag var jeg så igen hos den gæstfri familie denne gang sammen med læreren, som bar det klingende navn 
Carl Jakob Rosenkranz de Neergaard og skam stod i adelsårbogen. Han var nydimmitteret fra Gjedved seminarium, og jeg syntes straks godt om ham.

Vi talte om mangt og meget. Der var problemer overalt $\mathrm{i}$ det hårdt prøvede land, selv om krigen var forbi for et år siden. Mit personlige, øjeblikkelige problem var, forstod jeg snart, en vis hr. Bahnsen, formanden, som var betænkelig ved at antage nok en lærer. En såre forsigtig, omtænksom mand, hvis noble væsen jeg senere kom til at sætte overmåde højt.

Neergaard og jeg fulgtes ad derfra og snakkede nu privat. "Hør", fór det pludselig ud af ham, »De er da ikke missionsk? $\_$- Nej! Fik De indtryk af det? « — Nej egentlig ikke, men det kom sådan

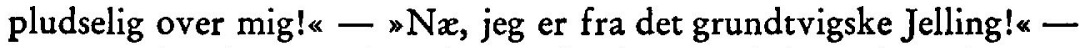
"Og jeg fra det grundtvigske Gjedved!« — Så lo vi hjerteligt, og det gjorde vi tit $\mathrm{i}$ vort udmærkede samarbejde vinteren igennem.

Søndag gik, og mandag kom. Bestyrelsen var sat, da Neergaard og jeg ankom, med forsær lidt sent. Man skulle have lov til i fred og ro at drøfte problemerne.

Så deltog jeg $\mathrm{i}$ det første rigtige sønderjyske kaffebord og blev præsenteret for bestyrelsen, som jeg på forhånd havde stor respekt for. Lad mig nu til gengæld præsentere bestyrelsen:

Formanden, urmager L. Chr. Bahnsen, rolig, ærværdig, gråsprængt, "orienterende sig «. Sekretæren, snedkermester J. Sorgenfri, lille, spinkel, intelligent og venlig. Kasserer Henningsen, kraftig og bred, med gråsprængt knebelsbart. Havde været med i krigen, var blevet hårdt såret, forhen malermester, nu livsforsikringsinspektør. Gårdejer Fink fra Ejsbøl, ung, livlig, energisk og meget sympatisk. Urmager Fahrendorff, smuk, midaldrende, ret en Poul Steffensensk herremandstype. Når jeg senere så ham ryge merskumspibe, gled uvægerligt et Poul Steffensen-billede frem for mit indre øje. Bogholder Foder, ca. 50 år, skaldet, spidst mundskæg, stilfærdig.

Dette var den øjeblikkelige bestyrelse, senere trådte redaktør A. Svensson til, da han flyttede til Haderslev og startede "Danskeren «. Det var disse mennesker, der var gået $\mathrm{i}$ spidsen for danske forældre, der »fandt skoleforholdene for dårlige« og nu påtog sig, $i$ betragtning af markens svage stilling, en okonomisk set meget krævende opgave.

$\mathrm{Da}$ kaffedrikningen var godt $\mathrm{i}$ gang, siger formanden: $» \mathrm{Ja}$, jeg 
véd ikke, hr. Sorgenfri, om De har antaget den nye lærer? « "Nej, det har jeg skam ikke. Det kan jeg da ikke på egen hånd «. Formanden: "Der er vel ellers stemning for, at vi antager ham, da han nu er her, og vi kender lidt til ham på en måde, da han har været lærer ved Skibelund efterskole? «

Samtykkende små ja'er bordet rundt, og den omhandlede person finder nu øjeblikket belejligt til at bemærke, at man ikke behøver at tage ham på det blotte ansigt: han har papirer med!

Alle praktiske forhold blev aftalt, derefter på cyklen og mod grænsen. $\mathrm{Da}$ skete det ubehagelige, at vejret slog om til storm, sne og slud - modvind! Cyklen pjaskede gennem sjap og søle. Det var et kapløb med tiden! Det skæbnesvangre klokkeslet nærmede sig, men det lykkedes at nå vagtstuen et par minutter før tiden. Jeg stak hovedet indenfor og sagde: "Jeg lovede at være tilbage inden 5! « Et nik og en håndbevægelse. At »klokken 5 « udløb for fire døgn siden, kom ikke på tale!

Lige efter min hjemkomst modtog jeg følgende brev:

»Hr. lærer Engelbrekt Pedersen, Svendsminde, Vejen.

Ifølge den af skolebestyrelsen trufne bestemmelse af 3 . november er De antaget som lærer ved "Den danske Privatskole« i Haderslev.

De har allerede fået et indtryk af, hvorledes forholdene er her, og har De, som jeg håber, mod og god vilje til at tage fat på de foreliggende opgaver, der $\mathrm{i}$ folkelig og national henseende er af ikke ringe betydning, så vil Deres tiltrædelse blive hilst med glæde.

Det vil være af vigtighed muligst snart at bestemme, hvilke bøger der vil blive brug for $\mathrm{i}$ de fag, $\mathrm{i}$ hvilke De vil overtage undervisningen. Jeg håber derfor at høre fra Dem med det første.

På bestyrelsens vegne

L. Chr. Bahnsen,

Haderslev, Nørregade 10.«

Brevet var sendt efter aftale og skulle bane vejen for udstedelse af det betydningsfulde pas.

Dansk politipas fik jeg hos politimesteren i Ribe, og så besøgte jeg den tyske konsul i Kolding for at erholde visum. Blankt afslag i forkontoret: Nordschleswig var plebicitområde, og ophold dér kunne ikke bevilges. Jeg fastholdt stædigt min begæring, og til sidst sendte kontormanden mig ind til selve konsulen, som viste sig at 
være en særdeles høflig og elskværdig mand. Vi talte længe om tingene, men omsider måtte jeg ud med mit bedste kort: bestyrelsesbrevet. En anelse hos mig slog til, da konsulen straks slog ned på de famøse ord: "... tage fat på de foreliggende opgaver, der $i$ folkelig og national henseende er af ikke ringe betydning .... * »Det er jo netop derfor, De ikke må komme derned! Landsdelen bliver afstemningsområde, og $\mathrm{De}$ må ikke være med $\mathrm{i}$ national agitation «. Jeg forsøgte at argumentere med, at min opgave ville blive at undervise - det eneste, jeg forstod mig på. Tyske lærere fik lov til at undervise ved danske privatskoler, og det var en privatskole, jeg skulle ansættes ved.

Så spillede konsulen sit trumfkort ud. "Se her et telegram, jeg lige har modtaget fra Berlin. Heri indskærpes, at der ikke må gives danske statsborgere opholdstilladelse i Nordslesvig! «

Derefter tog vi høflig afsked med hinanden. - Hvad nu? Sidste udvej: min gamle skolekammerat Alfred, som havde fået etableret en bilforbindelse mellem Vejen og Flensborg.

"Det er en kammerat af mig", sagde Alfred, da vi passerede grænsevagten for sydgående. Hånden til kasketten, og vi kørte til Haderslev. Ved tilbagekomsten mildnede en flaske whisky vagtens savn af mig!

\section{Haderslev.}

Pensionat havde jeg sikret mig under mit første besøg, men det var ikke lykkedes mig at finde et værelse i den krigsramte, boligfattige by. Under min søgen oplevede jeg et af de tilfælde, som måtte gøre indtryk på en tilflytter fra det neutrale Danmark. Jeg henvendte mig på grundlag af et forlydende $i$ en pæn to-etages ejendom i Storegade. En smuk xldre dame modtog mig. "Ja, De kunne godt have fået et værelse, men jeg har lige fået besked på, at min søn Willy kommer hjem fra fransk fangenskab. I to àr har jeg ikke vidst, om han var levende, og nu kommer han hjem «.

Hun var strålende glad, og hendes glæde smittede mig, så jeg nxsten glemte skuffelsen over ikke at kunne få det dejlige lyse værelse med porcelænsovnen. Et par dage efter belønnedes min medglxde, da jeg passerede huset sammen med en fælles bekendt. Damen åbnede vinduet og sagde, at nu var Willy nået til den hollandske grænse, og hun kunne vente ham om et par dage, og så viste 
det sig, at hun midt i glæden ikke havde glemt mig: hun havde skaffet mig værelse hos bekendte! Hos umådelig flinke mennesker, som jeg altid mindes med glæde, selv om vi i national henseende stod så skarpt som muligt over for hinanden. Det menneskelige holdt igennem alle diskussioner.

Endnu var spørgsmålet om opholdstilladelse tilbage. Jeg kunne ikke få udleveret ernæringskort på rådhuset på grund af mit manglende pas. Min pensionatsvertinde kunne ikke begribe, hvorfor det stadig trak ud. Igen var heldet med mig. Jeg havde en halvfæetter, som var ansat på rådhuset. Trods sit danske sindelag var han højt anskrevet hos den tyske borgmester von Schindelhauer. Jeg forklarede ham min situation og gav ham mit danske politipas, og sandelig om ikke passet vandrede fra rådhuset til den noble landråd von Løw, som viserede mit pas med ind- og udrejsetilladelse over hele tre grænsestationer! Så fik værtinden mine ernæringskort, og min halvfætters fader fik alle mine tobakskort.

\section{Den danske Privatskole.}

Privatskolen havde lejet sig ind $i$ to aftenskolelokaler $i$ Vestergade. Vi residerede der om dagen, og en slags handelsskole om aftenen, og det gik ganske gnidningsløst. De to rum var store og lyse. Børnene sad på langbenede taburetter ved lange borde. Primitivt, men solidt. $\mathrm{Da}$ børnetallet imidlertid voksede, måtte vi søge hjælp hos værtinden på det danske højskolehjem. Elskværdigt lånte hun os bænke, som sikkert ofte har bugnet under vægten af støtte danske, som sang efter »den blå .

Børnene var en broget flok med hensyn til kundskaber og færdigheder. Nogle havde været på skole i Danmark, andre havde modtaget privat undervisning hjemme, og en del kom lige fra den tyske skole og måtte begynde helt fra bunden, f. eks. gå fra de »spidse« til de "runde« bogstaver. De huggede løs med deres "hårde d'er ", så det lød ligefrem pudsigt, når Harda (datter af bankdirektør Schack Andersen) og Hans (søn af læge Meyer Petersen), som begge kom "nordfra «, satte ind med deres "åbne d'er«.

Undervisningsmidlerne var begrænsede - lærebøger, hæfter, kridt. Samlinger havde vi naturligvis ikke, og landkort måtte ikke føres over grænsen. Men vi kilede på med de hjælpemidler, vi havde, og børnene var flinke og interesserede - næsten uden undtagelse, 
skønt den tyske skolemoral var dalet stærkt under krigen. De mange "Siegestage", mens det gik godt, og de mange "Sammeltage «, da det kneb stærkt med fødevarer, havde demoraliseret den ellers så faste disciplin. Tit gik indsamlingen af bær $\mathrm{i}$ de mange levende hegn om byen for sig på den måde, at man drog ud i rad og række, men på åstedet arbejdede man $\mathrm{i}$ spredt fægtning, og snart listede læreren den ene vej, og børnene søgte deres egne græsgange. At alle unge lærere naturligvis var indkaldt til krigstjeneste, gjorde det nødvendigt at holde en meget stor klassekvotient, 50-60 børn i én klasse var almindeligt.

At vi aldrig konstaterede ulovlige forsømmelser, kan vel udlægges som et bevis på, at børnene var glade for privatskolen og onskede at lære noget. Naturligvis var det også af afgørende betydning, at forældrene "holdt dem til ilden « og glædede sig over at høre, hvad børnene lærte. Et vidnesbyrd herom fik jeg af en moder, som sagde: "Hvor er det fornøjeligt at høre børnene, når de er kommet i seng, ivrigt drøfte Rolf Krake, Gorm og Thyre«. At det med sådanne tilhørere var en sand fornøjelse at fortælle Danmarkshistorie, siger sig selv.

Helt slap vi dog ikke for kritik! Samme moders xldste datter var utilfreds, da hun kom hjem fra sin forste skoledag hos os. Skolen var begyndt, inden familien flyttede til byen, så datteren var »en ny pige«. Hvad synes du så om din nye skole? « spurgte moderen hende ved hjemkomsten. "Det er en dårlig skole. Der er ingen orden! — - Hvad vil det sige? — — Jo, jeg fik selv lov til at bestemme, hvem jeg ville sidde ved siden af! - Se, den slags letsindigheder fra lærerens side rimede sig ikke med tysk disciplin, som hun hidtil havde været undergivet!

Børnene kunne gennemgående mange danske sange, og de sang med liv og lyst. Hvor meget sangen havde betydet $i$ hjemmet, fik jeg en dag et levende vidnesbyrd om. Ind under jul havde min kollega en sangtime i lokalet ved siden af mit. Lydforholdene bevirkede, at vi ret godt kunne følge juletonerne: "Julen har bragt velsignet bud «. $\mathrm{Da}$ fløj en lille fyr $\mathrm{i}$ vejret med strålende øjne og sagde: * Ja, den synger vi, når juletræet er tændt, og så spiller mor till« Lidt efter hørte vi: "Nu har vi jul igen!« — $₫ \AA$ h, den synger vi altid, når vi går omkring juletræet! « Drengen hed Bjørn Svensson, søn af redaktør Svensson. Det var, som sikkert mange véd, hans 
søster Karen Margrethe, der i barnekammeret »dansede for Danmark « den 10. februar.

I det hele viste det sig, at børnene kendte en mængde danske bøger. Jeg måtte uvilkårlig mindes en bispevisitats i den lille skole nord for grænsen, hvor jeg var lærer i sommeren 1919. Biskoppen dvælede dér udførligt ved, hvilken oplevelse det ville blive for børnene i Sønderjylland efter genforeningen at lære H. C. Andersens eventyr at kende. De kendte så sandelig lige så mange af dem som børn $i$ almindelighed nord for grænsen, og børnebøger fra Ingemanns romaner til Niels $\mathrm{K}$. Kristensens havde de fået gennem Sprogforeningen eller fra slægt og venner nordfra.

Indadtil var alt således idyl. Udadtil var billedet ikke helt så harmonisk. De tyske myndigheder var naturligvis utilfredse med, at så mange børn blev udmeldt af den offentlige skole. Ret og slet at nægte udskrivelsen kunne de ikke. Nationalforsamlingen i Weimar havde den 11. august $1919 \mathrm{i}$ den nye grundlov (Weimarforfatningen) i $\$ 113$ udtalt, at der ikke måtte lægges *fremmede elementer $\mathrm{i}$ befolkningen* hindringer $\mathrm{i}$ vejen, når man ønskede modersmålet anvendt $\mathrm{i}$ undervisningen. At denne bestemmelse ikke kunne ske fyldest $i$ den offentlige tyske skole, var en selvfølge, og derfor måtte en privatskole være lovmedholdelig. Man greb da til den udvej at erklære skolen for ulovlig, da vi ikke havde tysk på undervisningsplanen, som var indsendt til myndighederne. Det var bestyrelsens udtrykkelige ønske, at al undervisning skulle foregå på dansk.

Erklæringen kom naturligvis ikke uventet, og urmager Bahnsen udtalte da også med sin sxdvanlige ro, at kunne de ikke ramme os på den ene måde, skulle de nok skabe os vanskeligheder på anden vis. Han mindedes, hvordan det var gået redaktør Jessen, „Flensborg Avis«, der var blevet afskediget som lærer på grund af »utilbørlig vandel «, skønt Jessen var det mest noble og retlinede menneske, man kunne tænke sig.

Den eneste udvej var at trække sagen $i$ langdrag. Dette skete ved fremsendelse af en ansøgning til Rigsregeringen. Det var kendt, at en afgørelse af denne art kunne lade vente længe på sig, og genforeningen kunne nu ikke vare fjern. Men så gik vor fjende nr. ét, byrådssekretær Jensen, i krig på anden vis. Han fandt ud af, at børn ikke måtte tages ud af den offentlige skole for at sattes i privat 
skole, der ikke var anerkendt af staten. Følgelig kunne forældrene idømmes bøde for børnenes ulovlige forsømmelser.

Der kom da ordre til bestyrelsen om, at den skulle sørge for, at samtlige børn mødte $\mathrm{i}$ de respektive skoler førstkommende mandag.

Ordren blev udstedt en lørdag, og bestyrelsen svarede naturligvis omgående, at man hverken ville eller kunne efterkomme ordren, da det drejede sig om børn fra 60-70 hjem, hvoraf mange var landbohjem. Svaret kom lige så omgående: Børnene ville blive afhentet af politiet, såfremt de mødte i privatskolen!

Mandag morgen mødte formand Bahnsen på skolen, da der jo var al mulig grund til at vente besøg. Jeg var alene, da Neergaard var blevet forsinket af et biluheld under et weekend-besøg i Nordjylland. Politiet kom dog ikke, og Bahnsen gik fredeligt hjem, og jeg arbejdede i ro. Det næste, der skete, var, at forældrene blev idømt bøder, men såvidt jeg fik oplyst, betalte ingen.

Senere fik vi alligevel politibesøg. En betjent kom med ordre til lærerne om at møde på rådhuset. Hans besøg forløb meget festligt. Efter at have afleveret den skriftlige indkaldelse fjernede han sig over skolegården midt $i$ et frikvarter. Lærerne havde modtaget ham inden døre og kunne således ikke forhindre, at han fik et hurra med på vejen, mens huerne fløj $i$ vejret!

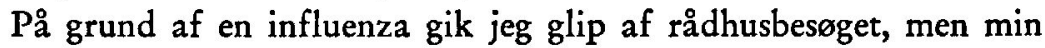
kollega mødte og blev forholdsvis elskværdigt behandlet. Man ville nu ved snild diplomati fælde skolen: Neergaard fik det tilbud, at han godt måtte forblive $\mathrm{i}$ byen (hvad de jo ikke kunne forbyde ham, da hans opholdstilladelse var $\mathrm{i}$ orden), hvis han ville opgive sin stilling ved skolen og undervise privat. At Neergaards svar var afvisende, kunne forudses!

Vi var naturligvis ikke ude på at skaffe os presseomtale, selv om konsulen $i$ Kolding frygtede noget $i$ den retning. Den, der lever stille, lever godt, og vi onskede blot at arbejde uforstyrret, hvad vi som omtalt ikke fik lov til, og så kom pressen ind i billedet. 26. november kunne man lre følgende notits $i$ et af byens blade -Modersmaalet «:

"Privatskolen ikke lukket.

Det er meddelt i flere blade, at den danske privatskole i Haderslev var blevet lukket af de preussiske myndigheder. Efter hvad 
nærværende blad erfarer, fra én af ledernes side, passer disse efterretninger ikke.«

Situationen tilspidsedes, og formand Bahnsen fandt det nødvendigt at indsende en besværing til dagspressen. Den fik denne opsætning:

"Tyske tvangsforanstaltninger imod en dansk skole.

Vi har modtaget følgende:

I disse dage foregår der noget her $\mathrm{i}$ byen, som vil vække opmærksomhed, ikke blot her, men i vide kredse. Vi har fàet en påmindelse om, hvad det tyske styre er i og for sig, og hvad det har været gennem mange træengselsår.

Endnu en gang, inden de forlader os, anser repræsentanter for tysk tvangspolitik det for betimeligt at gå angrebsvis til værks over for danske forældres forsøg på at lade deres børn få en skoleundervisning, der er i overensstemmelse med børnenes fremtidsvel for øje.

Angrebet gælder den for nogen tid siden oprettede danske privatskole her i Haderslev. Da den blev oprettet, blev det anset som en selvfølge, også fra skolemyndighedernes side, at dette var noget, der var fuldstændig lovligt og svarende til tidens krav i overgangstiden. Men man må være kommet på andre tanker.

Kredsskoleinspektør Røhr sender anmodninger til politiet om at undersøge skolens forhold, med det åbenbare formål at komme den til livs.

To af skolebestyrelsens medlemmer, Henningsen og Bahnsen, kaldes ned på rådhuset og får her af borgmesteren en forklaring, som går ud på, at denne skole ikke behager ham, og at den helst ikke burde være til.

Magistratssekretær Jensen, der efter borgmesterens udsagn navnlig har denne skolesag til bearbejdelse, giver os at forstå, at alt, hvad der vedrører undervisning, er afhængig af myndighedernes godkendelse. Forældrene har, efter hr. Jensens opfattelse, ikke spor af ret til selv at tage bestemmelser om noget desangående. Nogle dage efter kommer en politibetjent ind $\mathrm{i}$ skolen og anmoder læreren Carl Neergaard om at komme ned på rådhuset. Her søger magistratssekretær Jensen at skræmme læreren bort fra skolen, men hr. Neergaard mente dog ikke, at han uden videre ville gå sin vej og lade det hele i stikken.

$\mathrm{Nu}$ i de sidste dage har politiet gået rundt til adskillige forældre 
og opfordret dem til at sende deres børn tilbage til den tyske skole, da børnene ellers tvangsvis ville blive bragt tilbage dertil. Politiet har derefter bragt truslen til udførelse og har hentet flere børn ud af skolen og bragt dem hen $\mathrm{i}$ den tyske skole.

Således er den åndsfrihed, som den tyske socialdemokratiske republik har at byde på. I dens nye grundlov hedder det rigtignok $i$ artikel 113, at "rigets fremmedsproglige elementer ikke må indskræenkes eller hindres $\mathrm{i}$ deres frie folkelige udvikling, især ikke $\mathrm{i}$ brugen af deres modersmål ved undervisningen «, - men teorien er én ting og praksis en anden.

Skolens bestyrelse har indsendt en besværing til regeringspræsidenten over politiets adfærd, og vi vil vel derefter få at se, om regeringen billiger en sådan fremgangsmåde.

L. Chr. Bahnsen.

Forhåbentlig træffes der med det første en ordning, så undervisningen kan fortsæettes uforstyrret.

Red.*

3. december fremkom følgende svar:

^Den danske privatskole i Haderslev.

Som gensvar på hr. L. Chr. Bahnsens indlæg her $\mathrm{i}$ bladet har vi fra $\mathrm{hr}$. borgmester $\mathrm{dr}$. Schindelhauer modtaget en skrivelse, som her skal gengives i oversættelse:

I nr. 279 af "Modersmaalet « for 1. dec. 1919 giver hr. L. Chr. Bahnsen beklageligvis en falsk, fuldstændig forvrænget og vildledende skildring af den stilling, som de herværende skolemyndigheder har indtaget over for en dansk privatskole.

Sagens sammenhæng er denne:

Den 9. september havde skoledeputationen indbudt fire medlemmer af et dansk skoleudvalg, som havde dannet sig her, til en drøftelse af indførelsen af dansk undervisning, hvilket derpå også snart havde til følge, at der blev indført danske undervisningstimer. Ved denne lejlighed nævntes også hensigten at oprette en dansk privatskole, og af skolemyndighederne blev der for dette tilfælde på imødekommende måde stillet $\mathrm{i}$ udsigt at få de to klasser $\mathrm{i}$ Vestergade som lokale for denne privatskole.

Deraf turde med tilstrækkelig tydelighed fremgå, at skoledeputationen stillede sig absolut velvilligt over for ønskerne om at indføre danske undervisningstimer. 
Efter gældende bestemmelser kræves rigtignok til oprettelse af en privatskole statens godkendelse. Som det $i$ et sådant tilfalde er rimeligt $\mathrm{i}$ et ordnet statsvæsen, skal der føres beviser for, at de lærerkræfter, som ansættes, moralsk og videnskabeligt er $i$ stand til at undervise og så videre. Det skyldes forældrenes velforståede interesse, hvilket også hr. Bahnsen vil indse. Det er skolemyndighedernes pligt at forlange de nødvendige beviser. Måtte nu ikke også hr. Bahnsen og de øvrige medlemmer af det danske skoleudvalg på deres side føle det som en selvfølgelig pligt at gøre sig umage for at bringe den skole, de ønsker, $i$ overensstemmelse med de gældende bestemmelser og dermed at understøtte skolemyndighederne $\mathrm{i}$ deres bestræbelser for at få den ny privatskole oprettet, således at den er uangribelig set fra lovens standpunkt? En sådan umage har man imidlertid hidtil ikke mærket noget til. Privatskolen oprettes tværtimod uden den nødvendige godkendelse fra statens side; skoleudvalget tager uden videre to af byens skoleværelser $\mathrm{i}$ brug med dette mål for øje og råder egenmægtigt over fremmed ejendom. Børnene foranlediges til at forlade de skoler, som de hidtil har besøgt, og gå i privatskolen og så videre. Modne, alvorlige mænd skulle kunne sige sig selv, at en sådan ulovlig fremgangsmåde måtte fremkalde den største uorden og forvirring inden for byens skolevæsen, og at skolemyndighederne ikke kan tåle sådanne uordnede tilstande. I stedet konstruerer hr. Bahnsen, da han iagttager, at der truer med at opstå konflikter med myndighederne, et nyt tilfxlde af "tvangspolitik" for at vælte skylden over på skolemyndighederne.

Ansvaret for den konflikt, som muligvis måtte opstå og ikke kan undgås, rammer alene dem, der har sat skolen i gang. Forhåbentlig lykkes det imidlertid endnu ved forhandlinger med skoleudvalget at hidføre en tilfredsstillende ordning af sagen.

Dr. Schindelhauer, formand for skoledeputationen.*

Efter disse optrin faldt der ro over skolen. Danskerne var ganske på det rene med, at et svar fra regeringspræsidenten kunne lade vente længe på sig, og tyskerne havde sikkert en fornemmelse af det rigtige i H. P. Hanssens ord, da han allerede midt i juni 1914 på det store danske årsmøde $\mathrm{i}$ Haderslev følte, at men epoke var ved at rinde ud*. 
De store begivenheder omkring afstemningen satte naturligvis også sit præg på skolens forhold. Vi levede med i det hele sammen med eleverne, hvoraf mange var spejdere og derfor i høj grad blev brugt som hjxlpere ved de mange arrangementer.

Der skal ikke gøres noget forsøg på at gøre skolens resultater op. Eksamen afholdt vi naturligvis ikke, ligesom vi ikke $\mathrm{i}$ de enkelte klasser holdt os til et ganske bestemt "pensum «, som skulle leres. Dette var helt $\mathrm{i}$ overensstemmelse med Haderslev bys nye borgmesters opfattelse. Da redaktør Nicolai Svendsen var blevet udnævnt af Den internationale Kommission, aflagde jeg beseg hos ham for at orientere ham om, hvad der foregik i den lille skole i Vestergade. Som gammel skolemand var han overmåde interesseret og fremsatte den anskuelse, at vort arbejde først og fremmest måtte tage sigte på at indføre børnene $\mathrm{i}$ dansk skoleånd og give dem en orientering $\mathrm{i}$ danske forhold, der kunne virke vejledende og tillige som en appetitvækker, inden den systematiske undervisning efter genforeningen begyndte. Vore synspunkter faldt ganske $i$ tråd, og beseget blev indledningen til et venskab, som - trods aldersforskellen - holdt lige til amtsskolekonsulent Svendsens død.

At børnene i fagene dansk og regning fik eksakte kundskaber, rokker givetvis ikke ved vor principielle indstilling. Det kan da også nævnes, at adskillige forældre senere udtalte deres glæde over, at privatskolen havde hjulpet deres børn til en god start, da de fordeltes i de offentlige danske skoler efter sommerferien 1920.

Selv om vi var tilbøjelige til at betragte privatskolen som et lokalt anliggende, fik vi dog et vidnesbyrd om, at den vakte interesse $i$ »det gamle land«. 10. december 1919 lxste vi følgende indlæg i "Modersmaalet $\ll$ :

»Dansk og tysk skolevæsen.

Vi har modtaget følgende:

Med den største forbavselse vil en dansker læse et indlæg, som dr. Schindelhauers forleden om den danske privatskole i Haderslev; thi den opfattelse af "staten «s forhold til skolevæsenet, som lyser ud af indlægget, er så vidt forskellig fra dansk tankegang som vel muligt. Men det er altså den $»$ frie« tyske republik, som ikke tillader forældre at få deres børn undervist, som de vil have det!! Jeg gad vide, hvad de nordslesvigske tyskere ville sige, hvis danske skole- 
myndigheder engang i fremtiden opførte sig på lignende måde som dr. S. nu! - Fra dansk opfattelse vil man sige, at hvis forældrene ikke ønsker deres børn undervist i de offentlige skoler, så vedkommer det aldeles ikke staten, hvilke »videnskabelige og moralske kvalifikationer « de lærere er i besiddelse af, som forældrene kalder.

Den sag vedrører kun forældrene, og det kan de meget bedre passe end autoriteterne! Således ser vi på sagen i Danmark, og jeg tænker, at det lille tilfælde i Haderslev skal åbne øjnene for den afgrund, der er mellem dansk og tysk opfattelse af skolen.

Th. Adler Lund, lærer i Nakskov.«*)

\section{Byens ansigt.}

Kan det virkelig være muligt, at en by kan skæmme sig sådan i løbet af 6-7 år? Dette spørgsmål måtte man uvilkårligt stille sig selv ved gensynet med Haderslev i november 1919. Husene var i tydeligt forfald. Maling og puds manglede alle vegne. Butiksruder var adskillige steder erstattet af brædder, fortovene var yderst usikre at færdes på på grund af huller eller vippende fliser. Gadebelysning kendtes ikke. Man måtte klare sig med en lommelygte og gå midt på gaden. Faren for sammenstød med biler eller motorcykler var minimal. Derimod kunne fodgxngere godt finde på at opføre en lille sxlsom hinkeballet, inden de slap forbi hinanden.

En lille forsmag fik man allerede i »æ Kleinbahn « mellem Skodborg og Haderslev. Alt, hvad der kunne skæres af med en lommekniv, var fjernet. Altså kunne vinduerne ikke rokkes ud af stedet, men ruderne var dog i stand til at klirre, så man ikke kunne snakke sammen uden at sætte afrevne tændstikker i klemme mellem glas og karm. Selvfølgelig misundte man ikke de lykkelige mennesker, der nu gik med forhenværende jernbanelæder som skosåler, men indtrykket af et rige i forfald var stærkt.

Ikke alene fodtøj kneb det slemt med. Det var uhyre svært for en familie at holde tøj på kroppen. Husfaderen var måske bedst stillet. Hvis han havde været soldat, og hvem havde ikke det, kunne han slide de sidste rester af uniformen, og det gjorde han. Til børnene kunne man jo sy om, så længe man havde noget at sy om

*) Adler Lund kom selv med i genforeningsarbejdet som adjunkt, senere lektor ved Sønderborg statsskole. 
af, og hvad havde så mor, der måtte afgive alt, hvad hun på nogen måde kunne undvære?

Hertil kom naturligvis de fortvivlede pengeforhold. I ngamle dage « var en mark 80 øre, og man regnede $i$ det daglige ikke med nogen svingning heri. Der var fasthed og mening $\mathrm{i}$ tingene. $\mathrm{Nu}$ var marken faldet til kurs 10 , og priserne var roget tilsvarende $i$ vejret.

Et dagblad bringer en oversigt over prisstigningen:

\begin{tabular}{|c|c|c|c|c|}
\hline & \multicolumn{2}{|c|}{1914} & \multicolumn{2}{|c|}{1919} \\
\hline Et rundstykke & 0,02 & mk. & 0,30 & \\
\hline ikker ..... & 0,24 & $\star$ & 6,00 & \\
\hline Kaffe $\ldots \ldots$ & 1,50 & - & 15,00 & \\
\hline nar $\ldots \ldots \ldots$. & 1,30 & * & 25,00 & \\
\hline argarine $\quad \ldots \ldots \ldots$ & 0,70 & * & 11,50 & \\
\hline eked $\ldots . . . \ldots$. & 0,80 & $\bullet$ & 6,00 & \\
\hline$x g \quad \ldots \ldots \ldots \ldots$ & 0,08 & * & 1,50 & \\
\hline
\end{tabular}

Så høje var priserne. Til gengæld var mulighederne for at benytte sig af dem stærkt begrænsede. Ifølge rationeringen kunne hver person tilkomme 1 brød, $100 \mathrm{gr}$. smør og $200 \mathrm{gr}$. kød om ugen og hertil 1,5 pund sukker om måneden.

Lønningerne søgte at vinde med i kapløbet. En metalarbejder havde i april 1918 en timelen på 50 pfennig, i april 1919 2,00 mark, 30. jan. 1920 4,30 mark og 16. marts 1920 6,00 mark. Så hurtigt skiftede lønnen, men ikke fattigdommen. Først da kronemønten blev indført, 14. maj 1920, kom der igen stabilitet over økonomien.

Som altid spillede det pudsige ind $\mathrm{i}$ alvoren. For at spare på det kostbare brændsel gik min kollega og jeg ikke sjældent $\mathrm{i}$ biografen. En aften havde jeg ikke små marksedler, men betalte ved kassen med en femogtyveare og erholdt to reserverede pladser. Vi lo lidt ved tanken om, hvor billigt det var at gå i biografen, oven i købet på de dyreste pladser, men vi blev klar over, at det økonomiske problem næppe var helt $\mathrm{i}$ orden, da opsynsdamen $\mathrm{i}$ pausen nærmede sig. Jeg var rede til at yde kunsten et tilskud, men damen spurgte: "Var det ikke Dem, der betalte med danske penge ved kassen? " Jo, det var det. — „Vxrs'go', De har betalt for meget. De skal have en mark tilbage! «

Dyrtiden hang naturligt sammen med knaphed på varer. Landbruget blev forsømt. Arbejdet her var overladt til kvinderne og russiske krigsfanger. Alle mænd, som kunne bære våben, var ind- 
kaldt, og markerne var i høj grad forsømt. Det sparsomme udbytte af kvægavl og markernes afgrøde var under myndighedernes kontrol. Selv for landboerne kneb det med dagligt brød. I smug brændte man lidt korn til kornkaffe, og i nattens mulm og mørke kærnede husmoderen lidt smør på håndkværn. Gendarmen var den stadige trussel, selv om han undertiden faldt for fristelsen og reddede lidt af bondelandets goder hjem til kone og børn. Til gengxld vovede han at lukke øjnene for visse foreteelser.

Som altid under ekstraordinære forhold trivedes smughandlerne godt. Via dem kunne man tiltuske sig kostbarheder som f.eks. petroleum, en vare, man vanskeligt kunne undvære $i$ den mørke vinter $\mathrm{i}$ stald og lade.

I byerne var ernæringsforholdene naturligvis langt vanskeligere. Som før nævnt var rationerne så små, at man ikke kunne leve af dem, men måtte se at skaffe sig visse »tilskud «. Bønderne blev derfor daglig hjemsøgt af byboere, som ville tiltuske sig madvarer og $i$ mange tilfælde tilbød, hvad de endnu havde tilbage af værdigenstande fra de gode tider. Helt galt blev det, da store skarer fra storbyerne sydpå drog på togt nordpå. Helt fra Hamborg kom de, og det var vanskeligt at holde dem fra døren.

At det under disse forhold ikke var nogen nydelse at spise $i$ pensionat, var en selvfølge. Selskabet var ellers tiltalende, f. eks. en dansk bankmand af kernedansk Åbenrå-oprindelse og en højtkultiveret tysk dommer. Dommeren hørte til de humane embedsmænd, som tillod danskere, der havde svært ved at udtrykke sig klart på tysk, at bruge deres modersmål i retten. Han var meget interesseret i dansk litteratur. Jeg mindes en eftermiddag, da jeg efter opfordring gennemgik "Kong Christian " med ham!

Maden var ikke rigtig afpasset efter en »rigsdansk « mave. Frikadellerne var anselige af udvortes, men sank så underligt sammen, når man rørte ved dem, og i maven gjorde de ikke noget varigt indtryk. En hyppigt tilbagevendende ret var sursuppe, som helt svarede til sit navn, og stegt grisehjerne, som bibragte én et noget forgrovet indtryk af hjernevindinger, når man rystede den hvide substans lidt på tallerkenen. Måske betegner udtrykket et udtørret, krakeleret ørkenlandskab dog bedre rettens sande udseende!

Lidt kunne der bødes ved køb af en slags sukkerkringler $i$ en forretning nær ved privatskolen. Hvor sukkeret kom fra, spurgte 
jeg aldrig om, men sikkert er det, at visse biler fra Kolding kendte denne og andre lignende forretningers eksistens, for de kom på opkøb og har vel haft en valutabestemt fortjeneste ved videresalg af de søde sager nord for grænsen. At disse biler var ilde påset, er en selvfølge.

En helt usædvanlig begivenhed var det, at min godsindede værtinde en aften inviterede på friskslagtet grisemad - hvor de så har fået grisen fra. Såvidt jeg erindrer, reagerede min mave meget normalt over for dette usædvanlige måltid. Det gjorde den ikke over for min mors gode julemad, der hurtigt måtte gå over til "skånekost «.

Efter juleferien blev jeg pensionær på »Højskolehjemmet«. Det virkede stimulerende på kræfterne.

Overalt oplevede man små, tidstypiske træk. Således også på "Højskolehjemmet«. Blandt pensionærerne var der en ung tysker, tilflytter sydfra. Han var høflig og korrekt, en mørkhåret, kraftig type. Der herskede fredelig sameksistens, indtil en dansker $i$ samtalens løb brugte udtrykket "efter at den tyske hær var slået«. Da kom som en eksplosion fra tyskeren: "Den tyske hær blev ikke slået! Tyskland tabte krigen, fordi hjemmefronten svigtede! Vi blev ikke slået! « Disse ord skulle jo blive revancheønskets evangelium.

Midt i alvoren var der dog også rum for drengestreger. Jeg havde købt en salonriffel, og vi holdt undertiden skydeøvelser $\mathrm{i}$ "Højskolehjemmet «s store have. En dag indgik den omtalte tysker og en dansk bankmand et væddemål om, hvorvidt bankmanden kunne ramme den tidligere frontsoldat, hvis han stod på den anden side af Dammens inderste vig. "Skydeskiven" fik lov at trække frakkekraven op over nakken og vende ryggen til. Skuddet faldt, men kuglen ramte ikke! Om det var skyttens, bøssens eller barmhjertighedens skyld blev aldrig opklaret.

Om skydevåben var tilladt eller ikke, så man stort på, eller rettere: man så slet ikke på det. Ligeså $\mathrm{i}$ mange andre forhold. Jeg købte en dag en motorcykel, en "NSU « af den slags, der skulle løbes i gang, hvorpå man behændigt sprang op på »dyret«. Min undervisning bestod $i$, at jeg fik at vide, hvordan man startede og standsede maskinen, og alt gik udmærket uden kørekort og indregistrering, indtil flammerne en dag slog ud, da jeg befandt mig i nærheden af Styding. Jeg fik den bragt $i$ hvilestilling, men vidste 
så i øvrigt ikke, hvad jeg burde foretage mig. Da sprang en mand af cyklen, fór hen og væltede motorcyklen og begyndte at smide sand på den. Jeg gjorde ligeså, og da ilden var slukket, sagde han: "Sådan gjorde vi altid ved fronten, når der gik ild $i$ en maskine! « Det var jo meget godt at vide for fremtiden! Derpå asede jeg det noget medtagne køretøj hen til Styding station, hvor man var noget betænkelig ved at befordre det til Haderslev. "Vi må ikke køre med motorcykler med benzin på «, sagde togmanden. »Det skal De heller ikke«, sagde jeg; »den er brændt .

\section{Politik og hverdagsliv.}

Den 9. november 1918 blev den tyske republik proklameret, den 11. november indtrådte våbenstilstanden, og 13. november havde rigsdagsmand $H$. P. Hanssen en forhandling med de to regeringsmedlemmer Haase og Scheidemann. Allerede dagen efter tilkendegav dr. Solf på den samlede regerings vegne i et brev til H. P. Hanssen, hvordan den tyske regerings stilling var til det nordslesvigske spergsmål.

Det hedder $\mathrm{i}$ brevet:

"Den tyske regering står på det standpunkt, at også det nordslesvigske spørgsmål vil være at løse $\mathrm{i}$ overensstemmelse med præsident Wilsons fredsprogram på grundlag af vedkommende befolknings selvbestemmelsesret. «

"Vedkommende befolkning " svarede omgående. 17. november afholdtes det strålende folkemøde i Ãbenrå. "Flensborg Avis« skriver her om de tusinder, som flokkedes $\mathrm{i}$ »Folkehjem «s store sal og gange og på pladsen udenfor:

»Folk var fyldte af en glæde, som hverken var overmodig eller støjende, men dog lyste ud af hvert ansigt. «

H. P. Hanssen holdt sin store tale, som han ud fra sit sikre instinkt og sit følsomme sind sluttede med Bjørnsons ord:

$$
\begin{aligned}
& \text { Alt, hvad fædrene har kæmpet, } \\
& \text { mødrene har grædt, } \\
& \text { har den Herre stille læmpet, } \\
& \text { så vi vandt vor ret! }
\end{aligned}
$$

Men der skulle gå både vinter og vår og næste sommer med, omtrent, inden fredstraktaten var undertegnet, og genforeningen kunne finde sted. 
Her er ikke stedet til en gennemgang af alle de politiske problemer, som nødvendigvis måtte rejse sig, nu da realiteterne satte ind. De store linjer er jo for længst afklarede, men der vil stadig være træk, som glimtvis mere intimt belyser forholdene, og her må jeg naturligvis først og fremmest tænke på de glimt, jeg selv oplevede på nærmeste hold. Forstander la Cour Pedersen havde ret: det var sandelig mere værd at opleve genforeningsåret i Haderslev end at tilbringe tiden på Sølvgades kaserne.

I Haderslev »styrede« Arbejder- og Soldaterraadet byen. Den røde fane vajede fra kasernen $i$ god overensstemmelse med revolutionen sydpå. Den 7. januar 1919 meddelte dette råd, at man havde besluttet at sende to mand til regeringen $i$ Berlin for at forklare, at der absolut ingen stemning var i Nordslesvig for en landsdelsforening med Danmark.

Rådet fik svar på tiltale, da H. P. Hanssen talte første gang i Haderslev efter sin store tale $\mathrm{i}$ „Kløften « 1914, hvor der nu er rejst en mindesten. Der blev efter talen rettet det spørgsmål til ham: »Hvordan vil det stille sig med Arbejder- og Soldaterraadet ved afstemningen?" - H. P. Hanssen svarede: "Deres tid vil snart være forbi, til den tid er den $i$ alt fald forbi. De har $i$ det hele taget tilranet sig en myndighed, som ikke på nogen måde svarer til deres betydning. Når disse mænd, for det meste sydfra, vedtager resolutioner om Nordslesvigs fremtidige skæbne, er dette en utilbørlighed.«

Arbejder- og Soldaterraadenes røde fane vajede dog et stykke tid endnu, nemlig indtil Trikoloren afløste den.

Samme dag som Arbejder- og Soldaterraadet optrådte aktivt i grænsespørgsmålet, 7. januar 1919, kunne man læse følgende i dagbladene:

"Kvinder i Kolding har fået den idé at sende H. P. Hanssen, Nis Nissen og Kloppenborg Skrumsager hver et stort Dannebrogsflag af silke, der skal vaje over deres hjem den dag, genforeningen finder sted.« Det er jo andre toner. - Atter andre toner, klingende knap så sødt:

»Dannebrogsflag.

Et parti Dannebrogsflag sælges billigt, ca. 100 stkr. på $2 \mathrm{~m}$, ca. 125 fra 50 til $75 \mathrm{~cm}, 25$ stkr. på $1,25 \mathrm{~m}$. Nærmere ved henvendelse til

dekoratør N. N., København V.* 
Manden stiller altså hele lageret til rådighed - undskyld: købs!

Livets mangfoldighed illustreres yderligere:

„5 militærheste slagtes,

kød fås for 1 mark og 1 mark og 20 pfennig.

N. N., Haderslev."

Dette var en afveksling i kosten. Det er følgende ikke:

»Kålrabi,

god og sund handelsvare opkøbes. Fragtbreve fås på Landbrugstorvet, Haderslev.«

Side om side med det private sætter også det officielle initiativ ind:

"Sammel bog!

Krigsøkonomistedet i Haderslev opfordrer folk til at samle bog, thi indtil dato er kun indleveret ubetydelige mængder. «

Det tilføjes, hvor vigtigt det er at fremskaffe noget, der kan erstatte manglende fedtstof.

En særlig form for fremskaffelse af tilskud til de knappe rationer viser følgende annonce:

Grænsehandel!

Det er dyrt at drikke kaffe med kager. Vi giver intet traktement gratis. Hvorfor? Fordi reel handel er nr. 1.

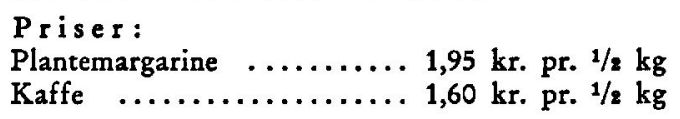

osv. - Underskrevet af 12 »grænseforretninger « i Danmark.

Disse og lignende forretninger var meget søgt, ikke blot af private, men også af "sortbørsgrosserere «. Der var indført passerseddel, men antallet af sedler var steget så overvældende, at borgmester Svendsen måtte foretage en revision, som foregik på „Højskolehjemmet « under voldsom larm og trængsel, så borgmesteren måtte alliere sig med nogle håndfaste mænd, der skaffede albuerum og til belønning erholdt det eftertragtede kort. Ekstraordinære forhold krævede ekstraordinære metoder!

Smugleri var naturligvis forbudt, men blev drevet i vid udstrækning. Der skete da også arrestationer ved grænsen, og der blev affyret skud mod smuglere; $i$ nogle tilfælde med døden til følge. Ikke alle fik så humørfyldt en udgang, som det P. Eliassen fortæller 
om i "Kongeåen «. En smugler var på vej hjem med en sæk mel på ryggen. Han blev forfulgt af en bereden gendarm, som skød efter ham, da han ikke ville standse. Sxkken smed han ind $i$ et sovekammer, men slap selv over grænsen. Senere har smugleren til minde om dagen og vel også om den beredne gendarm anbragt en morsom vejrfløj på sin samme år (1919) opførte lade. Fløjen viser en mand med en sæk på nakken forfulgt af en rytter!

\section{Tvangsterskning.}

Et af dagbladene bringer »efter pålidelig kilde« følgende:

"Landråden $\mathrm{i}$ Haderslev har givet Tolvmandsudvalget bemyndigelse til fra 17. november at begynde tvangstærskning hos de landmænd, der ikke har afleveret det kvantum korn til kredsen, som de skulle. Landmændene er forpligtede til at give tærskerne fuld forplejning. Nægter de dette, vil tærskerne blive forplejet på gæstgiverierne på vedkommende mands regning.«

På denne brogede baggrund begyndte den spændende fase ind under afstemningen. Den skarpe strid mellem » Åbenrå-folkene« og »Flensborg-mændene« gjorde tonen hård, men bidrog utvivlsomt til den vældige tilslutning til møderne. Genforeningen betragtede man som givet, men problemet Flensborg med eller Flensborg ikke med gav møderne det særlige præg og satte folk op mod hinanden, selv inden for den nærmeste familie. At H. P. Hanssen var indtrådt $i$ Zahles ministerium som "minister for sønderjyske anliggender", skærpede yderligere modsætningerne mellem de to grupper.

På møderne udfoldedes en fantastisk veltalenhed. Nok vidste jeg, at ikke alene de kårne førere, men også sønderjyder $\mathrm{i}$ mængde var dygtige debattører, men hvad jeg nu hørte, overgik alle forventninger.

Tonen var stærkt folelsespræget og alligevel realistisk. Det elegiske bar fremstillingen, også i pressen, som naturligvis måtte søge at være på højde med det talte ord.

Et lille eksempel kan vidne herom! Et uddrag af en leder $i$ et Haderslevblad den 28. juni 1919 lyder sådan:

"Hr. Pedersen Nyskov, der ellers sidder på sit formandssæede et par minutter før mødets begyndelse, dukkede $i$ går først op fem minutter efter klokken et, og en sær højtidelighed var udbredt over hans magre, blege ansigt. 
Pludselig står H. P. Hanssen i salen. Hans høje, kraftige skikkelse, hans kendte profil tegner sig mod vinduet ...

Uden for salen, i vandrehallen: hvilken tummel! Ikke en ledig telefon at opdrive! «

H. P. Hanssens indtræden i ministeriet Zahle vakte meget røre, og standpunkterne »for og imod Flensborg« blev skarpere. En bemærkning $i$ en avis er typisk:

»Der må optrædes kraftigt, hvis man skal undgå konsekvenserne af den holdning, som ministeriet (Zahle) har indtaget $\mathrm{i}$ den sønderjyske sag.«

\section{Afstemningen tilrettelagges.}

Uanset meningsforskelle skulle alle praktiske forhold ordnes. Eksempelvis kan nævnes, at en engelsk-fransk militærkommission den 11. december kø̣rte til rådhuset i Haderslev og efter et møde dér beså kasernen.

7. januar kom der melding om, at krydseren »Marseillaise « 4. januar var sejlet fra Brest mod København for at forrette vagttjeneste under afstemningen i Slesvig.

10. januar 1920 redegjorde overretssagfører P. Paulsen for transporten af de stemmeberettigede fra Danmark. Tallene kunne sættes til 21.000 , heraf 17.000 til deltagelse i zone $1,4.000$ i zone 2 . To skibe skulle gå til Haderslev. Hvis afstemningen skulle finde sted 10. februar, "skulle afrejsen foregå fra København kl. 8 aftenen før! « - Denne prognose holdt!

Så kom det stolte opråb, der slutter med ordene: "I syd og nord, $i$ øst og vest $i$ vor landsdel vil vi samles om det fælles mål, skal det lyde enigt som fra broder til søster: Vi vil hjem til Danmark!«

Jeg oplevede at høre dette manende opråb på det nystiftede blad "Danskeren«s kontor, hvor jeg havde meldt mig hos redaktør Svensson som ulønnet ekstraskriver for at være begivenhederne på så nært hold som muligt. Svenssons ildfulde temperament passede helt ind $\mathrm{i}$ situationen, da han $\mathrm{i}$ telefonen modtog opråbet - jeg véd ikke fra hvem. Han gentog sætning efter sætning og skrev dem ned, men pludselig skar hans stemme højt og skarpt igennem: $» \mathrm{Nej}$, det kan ikke passe! Det står der ikke! Nej - »den dør, vi har kæmpet imod « - det passer ikke! Man kan ikke kempe mod en dør! Nå ja, det var en anden sag: »den dør, vi har hamret imod!«« 
At jeg var fuld af beundring over Svenssons sprogsans, er en selvfølge.

Et andet frisk pust fra kontoret nogle dage senere: En høj, kraftig mand kommer ud fra det inderste kontor, knappende sin tykke ulster om sit svære korpus. "Ja, ja «, sagde han, "når nu blot Vorherre vil gi' wos nowwe godt wejr! « Det var felttoget i Sydslesvig, som var blevet drøftet, og manden var Kloppenborg-Skrumsager.

Den danske administration i Sønderjylland begynder. 12. januar overtager Refshauge embedet som landråd, efter Den internationale Kommissions bestemmelse. Samtidig offentliggøres den sidste tyske landråds afskedsbekendtgørelse. Friherre von Løw u. zu Steinfurt slutter således: "Som fra en anden hjemstavn tager jeg afsked fra dette land, hvor mit livsarbejde skulle være lagt, hvor mine børns vugge stod, hvor jeg har fundet lykke og tilfredshed i rigt mål og har lært prægtige mennesker at kende. - Gud beskytte dette land og dets beboere.

sign. Friherre von Løw

u. zu Steinfurt.«

Tre dage senere fik von Løw overrakt en adresse med tak fra 1500 sønderjyske kvinder for hjertelig forståelse af kvindernes vanskelige forhold under krigen. En retsindig mand, som havde gjort en stor indsats for at yde hjxlp i sit embedsområde, forlod nu landsdelen.

Også jeg burde have fremført en beskeden tak. Det var jo von Løw, der gav mit mangelfulde pas gyldighed, men at takke for landrådens utvivlsomme overskridelse af gxldende bestemmelser var jo ikke så ligetil!

En anden embedsmand, borgmester dr. Schindelhauer, stod ligeledes på falderebet. I det byrådsmøde, som blev hans sidste, erkendte han byens miserable tilstand og udtrykte håbet om, at købstaden under dansk styre *ville rejse sig som en Fugl Fønix af asken!*

På samme møde meddelte redaktør Nicolai Svendsen, at de danske byrådsmedlemmer agtede at bruge deres modersmål, efter at Den internationale Kommission havde overtaget regeringen $i$ landsdelen. Forhandlingerne blev derefter ført skiftevis på dansk og tysk, og det voldte ingen vanskeligheder, men det var unægtelig tegn på nye tider. 


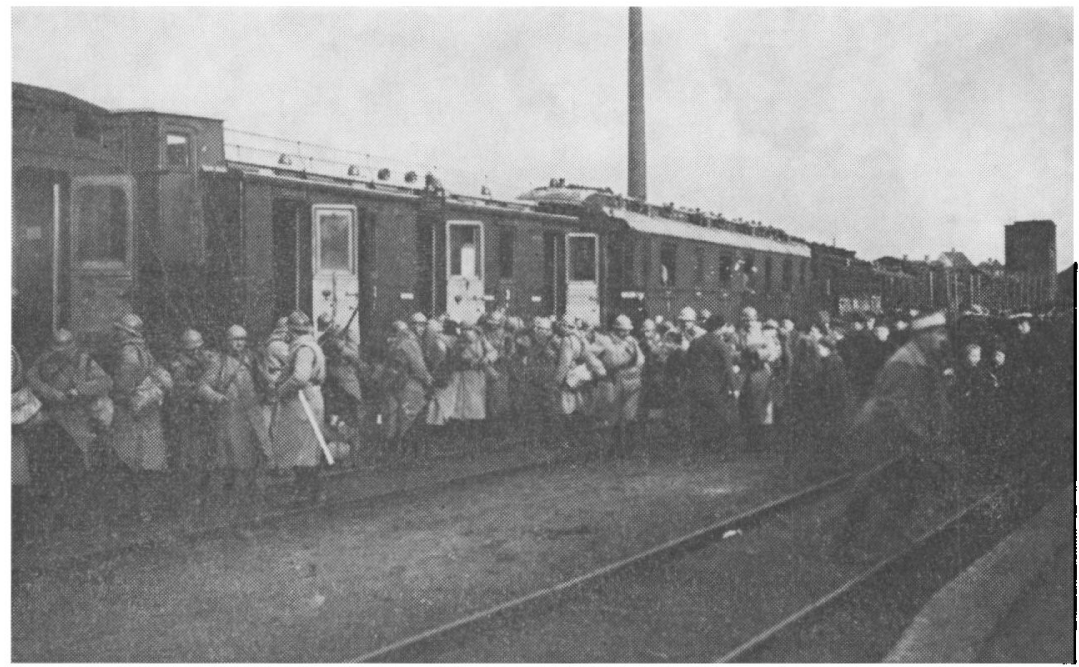

Alpejagerne ankommer 20. januar 1920.

Bestemmelsen om, at de tyske tropper skulle forlade Haderslev, trådte $\mathrm{i}$ kraft den 19. januar. Dansksindede borgere mindedes klart, hvilken prxcision og stolthed der havde præget garnisonens afgang til fronten 1914, og kunne nu konstatere, at al prxcision og stolthed var gået tabt. Jeg så det triste optog af fladvogne, som bragte de sørgelige rester af den stolte armés udrustning til banegården. Det meste bestod af gamle kakkelovne med tilhørende brænde - man skulle jo se at holde varmen $\mathrm{i}$ toget sydpå - og nogle småborde. Ialt rejste ca. 70 mand, de fleste vandrede enkeltvis gennem gaderne. En soldat udbragte fra vogntoget et noget forsinket "Leve kejseren “, og "Deutschland, Deutschland über alles" gjorde sig ikke i disse omgivelser.

Dagen efter, 20. januar, vil altid stå som en festdag $i$ byens historie. Gaderne, især Storegade, frembød et sælsomt syn: man stod på de hullede fortove og afbarkede friske granstammer. De skulle bruges som flagstænger, og sandelig: inden middag var gaden klædt i hvidt og rødt! Gamle ærværdige flag vajede side om side med nye. Ingen havde givet tilladelse til flagning, men rent spontant flagede man, og efterhånden også $i$ andre gader.

På Søndertorv foregik noget mere dystert! Et par arbejdsmænd 
kom med et stort sejllærred, og ganske stilfærdigt, men håndfast hyllede de kejser Wilhelm ind $\mathrm{i}$ lærredet.

Det var ekstraordinære foreteelser, men det ekstraordinære var over os - de franske tropper ville ved middagstid holde deres indtog! Naturligvis vandrede hele privatskolen til banegården, hvor vi $\mathrm{i}$ hundekulde ventede på det store øjeblik, da toget med alpejægerne skulle rulle frem. Måske var vi og mange med os kommet $i$ alt for god tid. Hvorom alting er, rygtet bredte sig pludselig, at vi godt kunne gå hjem og komme igen senere, da ankomsten var forsinket betydeligt. Der gik opløsning i rækkerne, og man var i færd med at forlade banegården, da det hastigt fløj gennem rækkerne: $\gg$ tyskere har udbredt det rygte, for at vi ska' blame'e wos, nær der ingen $x$ te' å ta' emod $x$ franskmænd!*

Straks vendte alle om, og alle holdt ud til klokken tolv. Da kom franskmændene, tilvinket og tiljublet på det hjerteligste.

Som det ses af billedet, myldrede soldaterne ud af de snævre kupeer, over skinnerne og stillede op, lidt sorgløst som gamle soldater måtte føle det efter en forlængst overstået kasernedisciplin, men en tysker bemærkede: «Rækken står jo helt skxvt! A Ak ja, hvis snorlige rækker havde været afgørende $i$ første verdenskrig, havde vi ikke set alpejægere i Haderslev.

Alpejxgerne marcherede gennem den flagsmykkede Storegade. Det læstes tydeligt $\mathrm{i}$ ansigterne, at de følte sig velkomne. De blev da også straks uhyre populære, ikke mindst på grund af deres musik. Midt under marchen kastede blæserne instrumenterne højt op i luften, greb dem igen med største sikkerhed og blæste videre. Dette ekvilibristnummer gjorde sig hver gang i den følgende tid.

$\mathrm{Da}$ de passerede den tæet tilhyllede majestxt på Søndertorv, smilede de så stort, som reglementet tillod, og det var ikke så lidt.

Marchen fortsatte gennem Nørregade til kasernen. Over kasernen vajede Trikoloren og tre Dannebrogsflag. Ikke ganske lovligt, men helt efter den store menneskemængdes ønske.

Den nyudnævnte landråd, Refshauge, bød de franske tropper velkommen på kasernepladsen, som frembød et farverigt skue: de blågrå soldater, de gule og blå spejdere, borgere $\mathrm{i}$ højst forskellige antræk - flere umiskendeligt af prøjsisk militæroprindelse!

At der fandtes en »modstandsbevægelse«, viste sig ved, at kejseren blev »afsløret«. Politiet skred ind, og majestaten forsvandt igen 
Kejseren fiernes fra sin sokkel på Sondertorv.

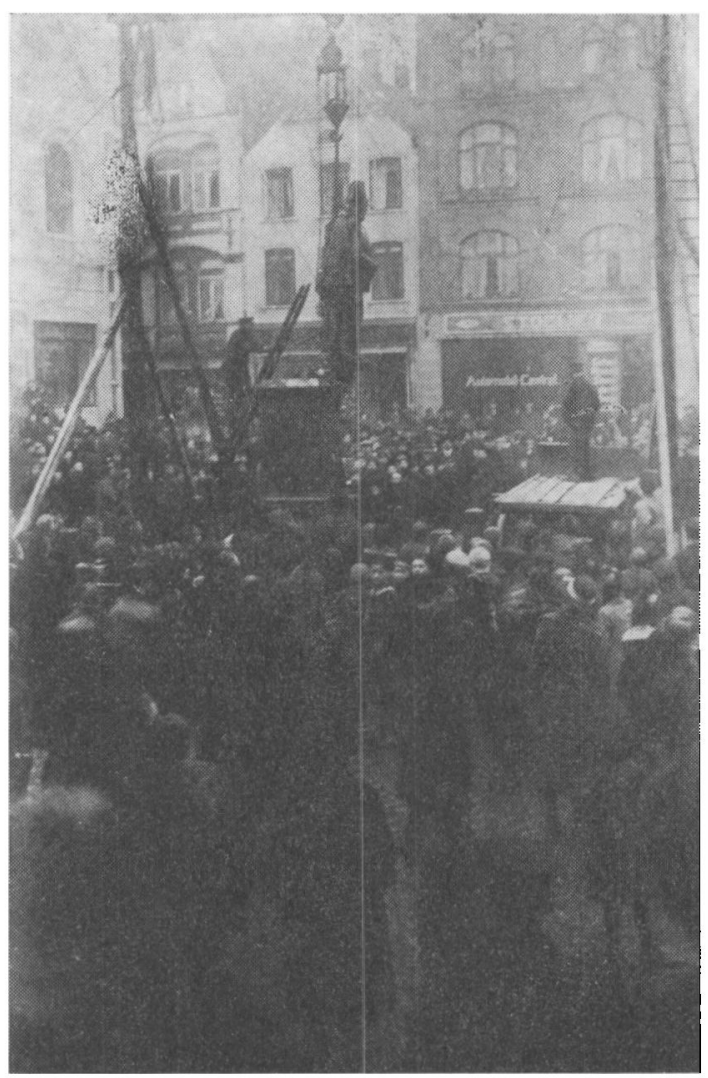

for vore blikke! Vi havde jo nemlig fået dansk politi. Frivilligt politi blev mobiliseret under det danske styre. Styrken stod under kommando af to gæve mænd, arkitekt Gydesen og politiassistent A. Jensen. En lastbil var arriveret med uniformskapper, danske ryttergeværer og armbind med mærket $" \mathrm{CIS} \ll=$ "Commission Internationale Slesvig".

Snart prægede alpejægerne bybilledet, og mange småepisoder refereredes: På en beværtning drillede nogle tyskere to franske underofficerer ved at spille "Deutschland" på mundharmonika. Franskmændene hamrede straks revolverkolberne i bordet, og musikken forstummede. Et yndet drilleri fra tyske skoleelevers side var pludselig at afsløre de tyske farver på bånd skjult under 


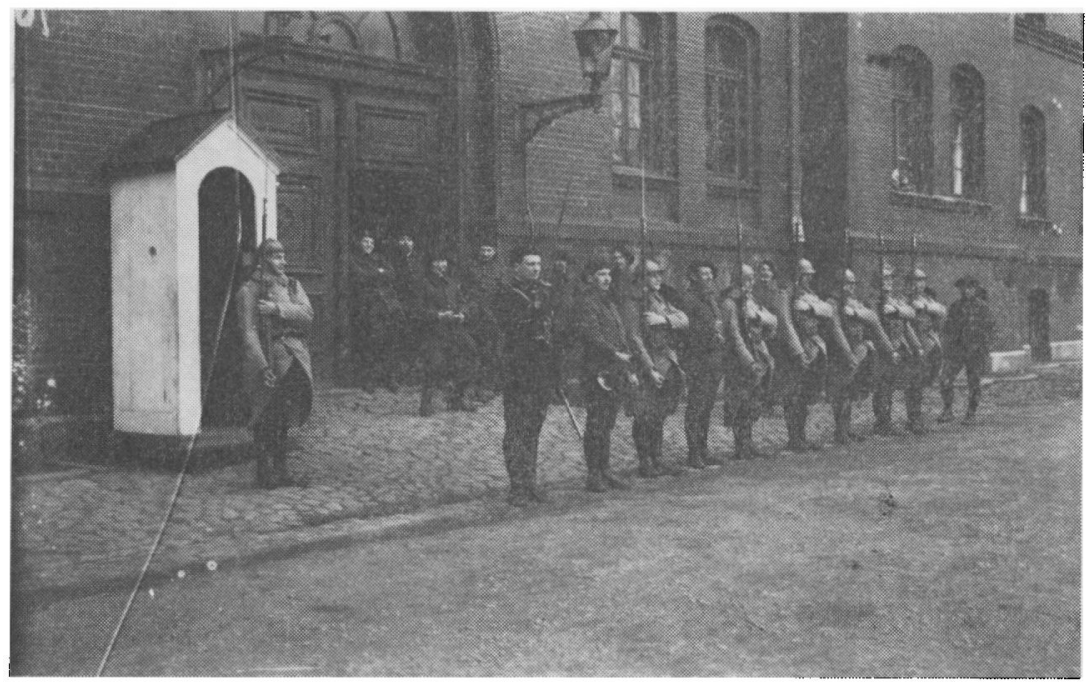

Alpejagerne har overtaget vagten ved kasernen.

trøjen. Jeg så engang to soldater rive båndene af en dreng. Ulovlig tysk demonstration, men nxppe "rettergang « helt efter reglementet, men hvad, gamle frontsoldater ordnede selv den slags småting.

26. januar gav jeg soldaterne følgende karakteristik $i$ et brev: »De franske tropper spadserer her uden for vinduet. Det er nogle små, bredskuldrede fyre, livlige er de, men kønne er de ikke.

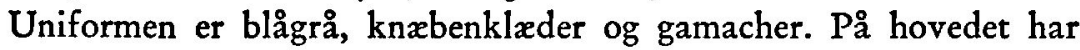
de en hjelm af form som en blikskål, undertiden en sort kalot. Det er nogle af Frankrigs bedste soldater. De har været med ved sejrsfesterne i Amerika. Officererne er behængt med ordener, og alle menige har et udmærkelsestegn. De går meget fredeligt omkring og er perlevenner med byens drenge.*

Naturligvis blev der festet. Tilstrømningen var så stor, at $\gg \mathrm{Nis}$ Juhl « måtte indrykke $i$ aviserne, at hotellet ikke havde kopper nok! »Husk at bringe kager og sukker til hotellet inden aften!« Og altså kopper! På den måde reserverede man bord!

26. januar holdt byen officiel velkomstfest for soldaterne. Salen var fyldt længe før tiden. Udtrykket $i$ aviserne "som sild $i$ en tønde« var korrekt. Kommandanterne Soyers fra Sønderborg og Cuny fra Haderslev mødte i spidsen for soldaterne. Høhns orkester spillede, 


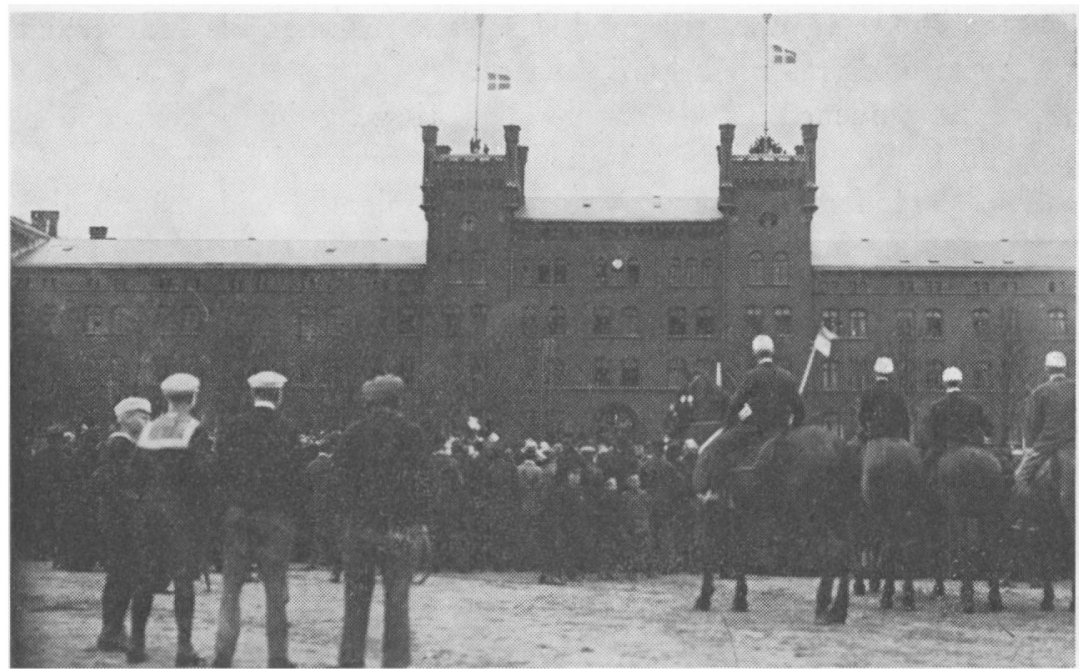

Dannebrog hejses. Ikke alle får huerne af eller handerne af lommen!

og Hanne Jenssen talte bevæget om Sønderjyllands gæld til Frankrig. Ungdomsforeningen gav på scenen opvisning i folkedans, franske soldater optrådte, militærmusikken skingrede, hornene fløj højt i vejret, helt på linje med stemningen $\mathrm{i}$ salen.

Kreditforeningsdirektør Callø talte på et fransk, som efter hans eget udsagn havde den fordel, at det kunne forstås af alle. Det kunne det. I hvert fald af os danske. I øvrigt var tolken, Fritz Schmidt, til rådighed, også som sanger, idet han foredrog $»$ Dengang jeg drog af sted « på fransk. Franskmændene kvitterede med et leve for Danmark, og nu kom aftenens højtideligste øjeblik: Trikoloren blev ført frem på scenen, syet af fru stiftsfysikus Madvig 1871, da man håbede og troede på Frankrigs sejr over Tyskland.

At man flittigt sang af "Den blå $\propto$, var en selvfølge.

Dagen efter, den 27. januar, blev kejser Wilhelm I fjernet, altså på Wilhelm IIs fødselsdag, som så tit var blevet fejret her $\mathrm{i}$ byen under ganske andre omstændigheder. Jeg stod blandt de mange tilskuere under det makabre skuespil, hvor statuen blev løsnet fra soklen, ved hjxlp af en kran hejset op og lagt på en fladvogn. Sit foreløbige opbevaringssted fik statuen $\mathrm{i}$ den tyske $\bowtie$ Bürgerverein $\kappa$. 
En mand søgte at protestere mod fjernelsen, men han blev stilfærdigt trukket ned, og resten forløb i tavshed.

Franskmændene ønskede at yde noget til gengxld for den venlighed, de mødte. 2. februar indbød de til fransk koncert på »Nis Juhl « for Haderslev by og 3. februar for oplandet. Sidstnæevnte dag var der tillige fakkeltog gennem byen. De hjemmelavede fakler blev hurtigt udsolgt. Fakkelbærerne stillede op på kasernepladsen og drog derfra med hornmusik i spidsen gennem gaderne. I vinduerne stod der røde og hvide lys, og danske og franske flag vajede $i$ gaderne. Masser af landboere fulgte sammen med byens borgere fakkeltoget $i$ en tusindtallig skare.

Nogle elever fra det tyske seminarium søgte at demonstrere, og et par af dem blev holdt tilbage af politiet. Et andet sted opstod der en sangerkamp. Tyskerne sang "Schleswig-Holstein-visen " og »Deutschland «. Danskerne svarede med danske sange, og kampen endte med, at tyskerne kørte træt, overdøvet af overmagten!

Hver dag bragte nyt. 4. februar besøgte generalsekretæren i Den internationale Kommission Haderslev og afsatte her på kommissionens vegne borgmester $\mathrm{dr}$. Schindelhauer og konstituerede $i$ hans sted redaktør Nicolai Svendsen, der således blev byens første danske borgmester efter 1864. Dagen efter bragte "Dannevirke« følgende meddelelse:

"Efter at jeg $i$ går af Den internationale Kommission er blevet konstitueret som borgmester for Haderslev by i kommissionens forvaltningstid, fratræder jeg herved foreløbig som udgiver og redaktør af nærværende blad.

Haderslev, 5. febr. 1920.

\section{Nicolai Svendsen.«}

Meddelelsen om udnævnelsen af en dansk borgmester blev naturligvis modtaget med glæde, og de danske aviser var enige om, at "man vanskeligt kunne finde en mere egnet mand «.

\section{Afstemningsdagen.}

$\mathrm{Nu}$ nærmede den største og mest spændende dag sig hastigt, afstemningsdagen. Danske og tyske valgplakater prægede byen, afstemningssteder var udpeget og valgbestyrelser nedsat, men bag det officielle rørte sig det private! Den ulykkelige bestemmelse, at alle, der var født $\mathrm{i}$ området, havde stemmeret, selv om de ikke havde 


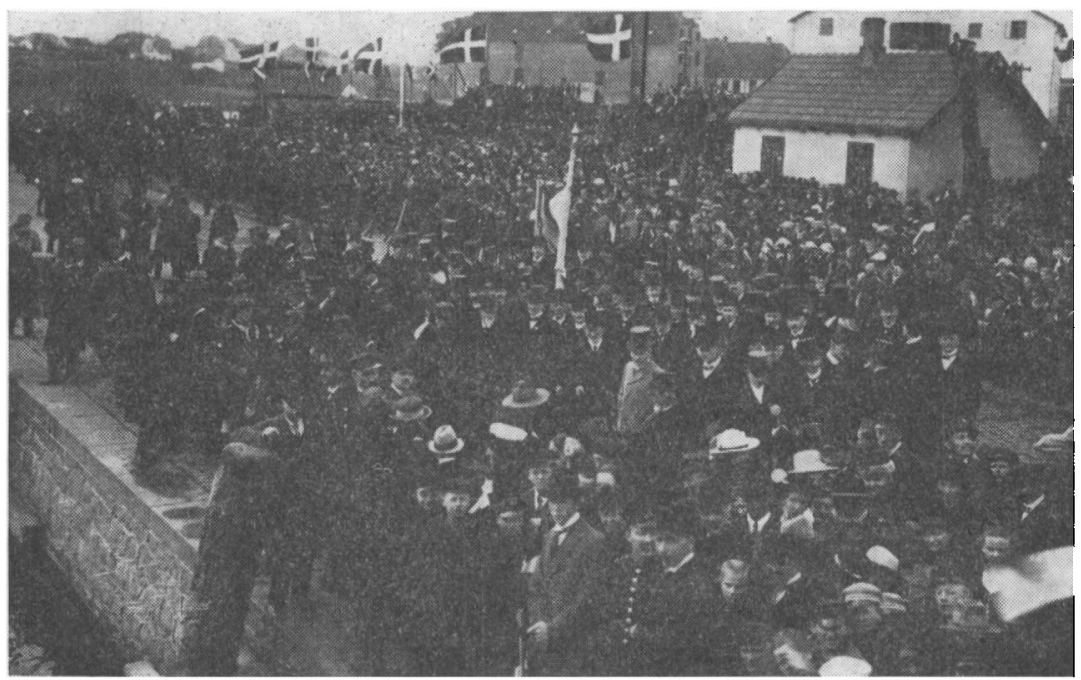

Alpejagerne og byens høje hatte venter pa de danske soldater.

haft egentligt ophold der, medførte, at børn af de mange hyppigt skiftende tyske embedsmænd kunne stemme. Naturligvis kom dette også rigsdanske til gode samt udvandrerne til andre lande, og her satte det private problem ind. Modtagelsen af de mange gxster voldte husmødrene bekymring. Hvordan skulle de kunne beværte de kære gæster så godt, som de ønskede, og som dagen krævede det, når gassen var hårdt rationeret? Det var komplet umuligt at tilberede et festmåltid med rationen. Man søgte da ekstrabevilling, og bevillingen svarede helt til stundens storhed: uafbrudt gas! Så kunne de opsparede goder samt de gavmilde tilskud nordfra vederfares retfærdighed.

Det første skib med afstemningsberettigede nordfra kom ind ad den smalle Haderslev fjord. Myndighederne, og hvad der ellers var af høje hatte, (og det var mange!) var mødt op sammen med store, brogede folkeskarer. "Brogede« var også de, der steg i land. Naturligvis kontaktede vi så mange, vi kunne overkomme. Mange havde ikke været i hjemstavnen, siden de udvandrede $i$ halvfemserne. Jeg talte med en mand, som trods 30 år i Australien havde sit sønderjyske $\mathrm{i}$ behold. Han pegede op mod et hus tat ved havnen. "Der er $æ$ føjt! « sagde han. 
Sammen med Åbenrå-bankmand Koch havde jeg fået det hverv at tage med én af amtsbanerne og hjælpe xldre afstemningsgæister til rette. Det blev en festlig rejse. På alle de små banegårde var der stor modtagelse. Flagene vajede, og mange rørende gensyn fandt sted. Vi var som én stor familie. Ikke alene tankerne om den store dag optog sindene. De tab, som krigen havde forvoldt, og som i familierne dengang måtte bxres på afstand, satte sit præg på ansigterne. Men mon det ikke gik mange, som det var gået formanden for privatskolen i Haderslev. Han udtrykte engang over for mig sin taknemmelighed over, at den store tid mildnede tabet af en søn.

Fra Gram sendte jeg mine forældre en hilsen, hvori jeg skrev, at »Far er sagtens på denne side grænsen, når I får kortet «. Det var han, sammen med to brødre. Først havde jeg overstået et så voldsomt anfald af »Tante Tandpine«, at alt vedrørende afstemning, tid og sted ganske svandt ud af min bevidsthed, men lykkeligvis veg damen for en god portion Aspirin, og fredeligt rullede det tomme tog tilbage, efter at have kørt sin mærkeligste og glædeligste tur!

10. februar! Alle i landsdelen, som oplevede den, glemmer ikke stormen og den piskende regn. Men ud skulle flagene, selvom de gamle, mørnede ikke kunne tåle overgangen fra stuestilhed til storm. Haderslev helt hvidt og rødt var et syn værd at se. På min morgentur rundt $\mathrm{i}$ gaderne mødte jeg Peter Marcussen, min tilkommende kollega, og lidt senere overraskedes jeg ved at se en kendt høj skikkelse, seminarieforstander Skat Rørdam, min forstander fra Jelling. Stemmeret havde han ikke, men sindelaget havde han og følte måske, at han ved sin nærværelse bragte hilsen fra det seminarium, som var oprettet med særligt henblik på Sønderjylland.

Rørdam inviterede os med på en biltur til Abenrå og Sønderborg, hvor vi "skulle tælle flag «! I Haderslev var der ikke mange oppe, men konkurrencen ville sikkert være større $\mathrm{i}$ de to andre byer. Det lykkedes at få fat $i$ en vogn, ikke af de mest komfortable, men dog i stand til at krydse sig frem mellem de dybe, vandfyldte huller på vejen sydpå. Stormen hev og sled $\mathrm{i}$ kalechen, men efter hård kamp nåede vi Ảbenrå og. begyndte optællingen. Tallene husker jeg ikke mere, men vore bange anelser slog til: det var ikke muligt $\mathrm{i}$ god tro at erklære de danske flag for at være i flertal. 
Ejendommeligt var det at se den mosaik, der dannedes af danske og tyske flag på husvægge og hængt ud af vinduerne. Dansk på 1. sal til venstre og på 2. sal til højre, tyske flag på 1. sal til højre og 2. sal til venstre, på kvistene spredt fægtning. Hvilket sprog talte beboerne mon, når de mødtes på den fælles trappe? De har nok alle dagen igennem sagt: "Mojn «! Vinden blaste, regnen regnede, og min ret nyanlagte sønderjyskprægede pelskrave, løstsiddende, led stærkt under klimaet, så Rørdam drillede mig med, at jeg lignede en druknet kanin. Det var ikke pænt, men sandfærdigt.

Sønderborg måtte vi opgive, hvis vi i passende tid ville nå hjem til Haderslev.

Resultatet af afstemningen blev som bekendt 75.431 stemmer for Danmark og 25.329 for Tyskland. 1. zone havde stemt sig hjem til Danmark.

Alle afstemningslokaler var stuvende fulde. Sangen lød, afbrudt af oplrsning af resultater, og stemningen steg, efterhånden som de fine tal fra landsognene nordpå kom frem. "Tyskerne er blevet hjemme«, var én af kommentarerne. Nogle resultater fra sydlige sogne og fra Tønder, Åbenrå og Sønderborg dæmpede i nogen grad humøret, men man var klar over betydningen af de tilrejsendes stemmer. Slutresultatet kunne der ikke rokkes ved: vi vandt vor ret!

Lunets sønner fornægtede sig ikke. Vittighed: Tyskerne er jo rene Diogenes'er. - Hvordan det? - Jo, afstemningen viser jo, at de fleste af dem bor i Tønder! - Når Tønder udtales på sønderjysk, er vittigheden acceptabel!

Dagen derpå var der takkegudstjeneste $\mathrm{i}$ kirkerne, og senere drog et mægtigt flagtog gennem byen.

Hvordan så nu tyskerne på resultatet? „Flensburger Nachrichten « skrev: "Langt over 90 pct. af de stemmeberettigede har stemt. Det er en valgdeltagelse, der giver folkeviljen et så klart udtryk som overhovedet muligt. Navnlig har Nordslesvigs landbefolkning overvejende stemt dansk, medens de fire byer opviser en stærk modvægt af tyskere «.

Dette må kaldes en nøgtern bedømmelse.

"Flensburger Volks-Zeitung «: "Danskerne i 1. zone fik et sikkert flertal. Dog har Tønder, Ābenrå og Sønderborg vist, at det tyske element er fremherskende langt nord for den Clausenske linje. En retfærdig grænse burde gå nord om Tønder «. 
Afstemningsdagen forløb fredeligt. En lille episode var der dog. På seminariet og præparandskolen hejstes det tyske flag, men kaptajn Cuny beordrede dem taget ned. Den internationale Kommission havde forbudt flagning fra offentlige bygninger. Lidt tragikomisk virkede det, da det blev kendt, at tyskerne havde fjernet flaget over kommissionens kvarter, "Flensburger Hof ".

Dagligdagen fulgte, men præget af overgangen til dansk administration. 14. februar holdtes det første byrådsmøde under Nicolai Svendsens ledelse. Det tyske medlem, tømrermester J. Jürgensen, formulerede en kort tak til den afgåede borgmester, dr. Schindelhauer. En stor del af befolkningen ville bevare et godt minde om ham i deres hjerter. Samtidig hilste han Svendsen som borgmester og udtalte: "Jeg tror, at han ved sin frisindethed og sit kendskab til tysk kultur vil vide, hvad vi ønsker af ham «.

Direktør Christensen, Slotsvandmøllen, kunne ikke tiltræde takken til en borgmester, som »kom langt nede fra syd, og som ikke engang her på 20 år havde gjort sig den umage at lære befolkningens sprog $\alpha$.

Kongen havde sendt byrådet sin hilsen, men forslaget om et takketelegram kunne kun tiltrædes af de danske medlemmer.

De danske aviser bemærkede, at forhandlingerne forløb sagligt, men var præget af en usædvanlig fart!

\section{Flensborg.}

Bestemmelsen om, at afstemningen skulle ske »en bloc « $i$ en nærmere fastsat del af Sønderjylland, kaldet 1. zone, blev ganske vist udvidet med adgang for beboere i 2 . zone til at stemme kommunevis, men denne ordning, der af mange opfattedes som en forhånds grænsedragning, blev hårdt kritiseret af »Flensborgbevægelsen «, som krævede, at alt blev gjort for at føre landsdelens hovedby hjem til Danmark. Her skal blot anføres, hvor spændende for ikke at sige gribende det var at overvære kampmøderne, hvor mænd som redaktørerne Christiansen og Tage Jessen, Flensborg, talte deres bys sag, kraftigt støttet af Kloppenborg-Skrumsager, advokat Andersen og mange flere. Landdagsmand Nis Nissen forsvarede Vælgerforeningens standpunkt, som den strålende debattor han var.

Et enkelt møde kan kort refereres. Det fandt sted hos $" \mathrm{Nis}$ Juhl « og talte ca. 800 deltagere. Det var »Flensborg-folkene«, der 
havde indkaldt til mødet, og hovedtalerne var redaktør Christiansen og Kloppenborg-Skrumsager. Redaktør Christiansen fastslog indledende, at spiren til det sidste års ufred blev lagt på Åbenråmødet 17. november 1918. "Enten må vi drive Zahles politik eller dansk sønderjysk politik «. Taleren mindede om de danske spirer, der nu sporedes i Flensborg, hvor man kunne høre børnene synge danske viser på gaden. Taleren ville protestere imod, at man kaldte de danske i Flensborg for en indvandret koloni.

Kloppenborg-Skrumsager: „For mig ville det falde uendelig tungt, hvis vi skulle forenes med Danmark uden de sydlige forposter «.

Nis Nissen havde den opgave at argumentere mod mødeindkaldernes talere. Han var ude for hyppige afbrydelser og mødtes med tilråb om Zahle. Bragt $\mathrm{i}$ affekt svarede han: »Jeg er ikke identisk med Zahle, men jeg taler på Vælgerforeningens flertals vegne!« Stadige tilråb om Zahle og et skarpt svar: "Det er løgn, når det siges, at flertalsgruppen er afhængig af Zahle i nogen retning! «

Advokat Andersen spurgte, om Nis Nissen ville nxgte at tage Flensborg med med et mindretal af stemmer. Nis Nissen: $\gg$ Det kommer an på, hvor stort dette er! « Advokat Andersen: "Byen skal med til Danmark, selv om det danske mindretal bliver nok så ringe! «

Trods al uenighed sluttede mødet på god traditionel vis med, at alle stånde sang "Kongernes konge«.

Jeg sendte et referat af dette møde til »Jyllands-Posten«, med næb og kløer. Bladet bragte det ikke, da bladet havde sin mand på stedet. Senere fik jeg at vide, at bladet ville have bragt mine produkter, hvis jeg havde fortsat, hvad jeg ikke gjorde. Jo, jeg var "Flensborgmand " af fuld overbevisning. Jeg sluttede mig til dem, der ikke ville godkende, at tiden udnyttet gennem fortyskningsbestræbelser berettigede Tyskland til at beholde det, som de med magt havde røvet.

Spændingen steg, eftersom den afgørende 14. marts nærmede sig. Søndagen før afstemningen var jeg i Flensborg, overværede danske møder og deltog i optog i gaderne, hvilket ikke gik af uden puf og sangkrig.

Resultatet af afstemningen udløste en dyb skuffelse, selv om dog 20 pct. af befolkningen havde stemt dansk. De tyske tilrejsende var også her i stort flertal. Man regnede med, at det danske stemmetal ville have nået 24 pct., såfremt kun den stedlige befolkning havde haft adgang til at stemme. 


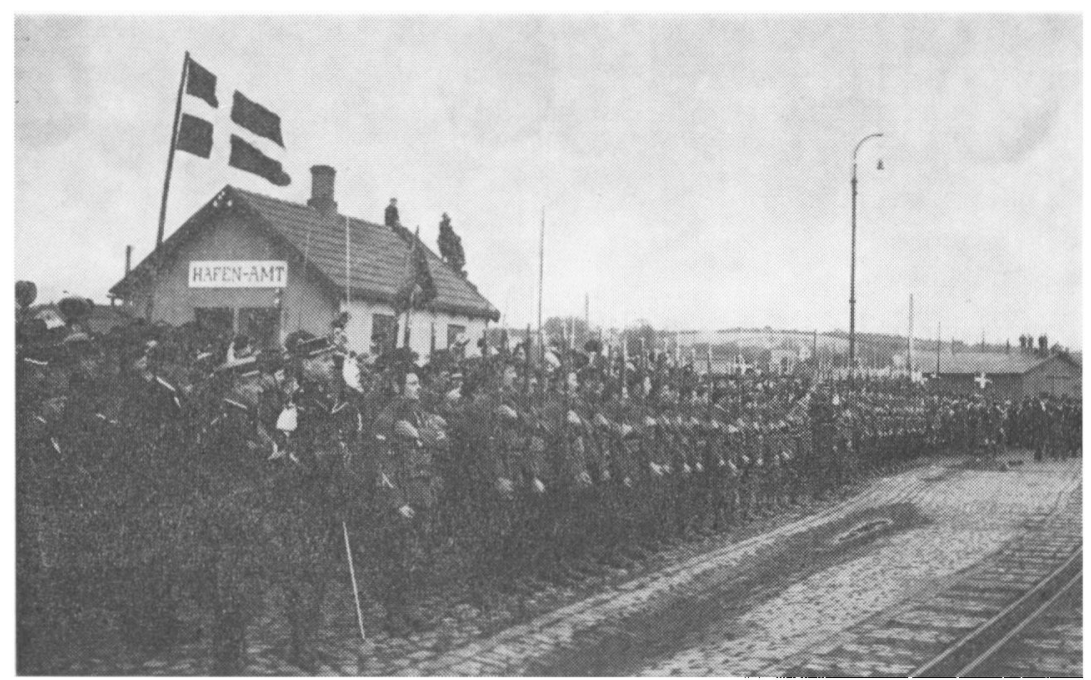

Alpejagerne modtager de danske soldater på havnen.

De følgende bestræbelser for $\mathrm{i}$ hvert fald at redde Flensborg med til Danmark gav ikke det ønskede resultat, men medførte dog, at det blev Neergaard og ikke Zahle, der som regeringschef skulle modtage Sønderjylland. Det fandt jeg ræson i.

\section{Danske soldater og danske kroner.}

Den internationale Kommissions hovedhverv: gennemførelsen af afstemningen var nu udført, og grænsen blev på fredskonferencen fastsat $i$ overensstemmelse med afstemningsresultatet, men der var meget at ordne, inden genforeningen kunne finde sted. Hertil hørte de danske soldaters ankomst 5. maj og kronemøntens indførelse 14. maj. Det første var festligt og rimeligt, det sidste absolut nødvendigt, så elendigt som den tyske mark stod.

Som det sømmede sig en sønation kom de danske »Jens'er “ sejlende til Haderslev, selv om de var landsoldater. Borgmester Nicolai Svendsen bød soldaterne velkommen under jubel fra store menneskemasser. Alpejægerne dannede front mod deres danske kolleger, og morsomt var det at sammenligne de små blågrå franskmænd med de høje lystklædte danskere. Pudsigt var det også at bemærke det ryk, det gav i franskmændene, da danskerne tog de behørige gevær- 


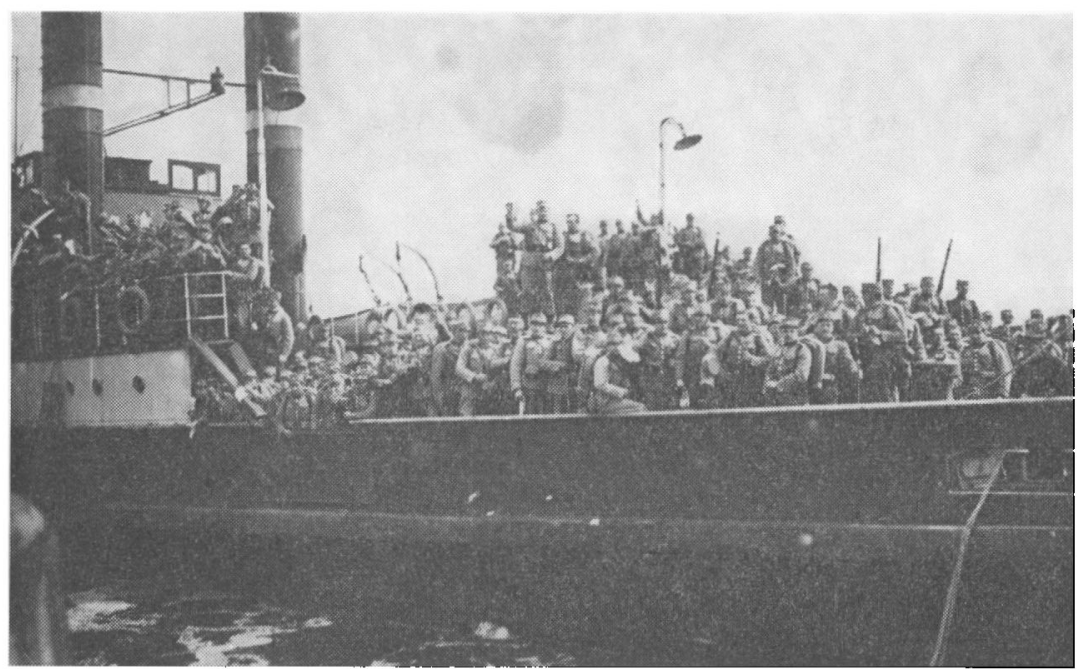

De danske soldater står fjorden ind.

greb med smæld, som var elitesoldater værdige. Vi var enige om, at de havde øvet sig!

Under marchen gennem byen fik Frankrig revanche. De gik i spidsen, hornene skingrede og glimtede, franskmændenes ben gik som trommestikker, og de langbenede danskere havde det største besvær med at trippe $\mathrm{i}$ takt.

Soldaterne gjorde holdt på kasernepladsen. Trikoloren gled ned ad flagmasterne, og Dannebrog gik til tops, denne gang for at blive. Snart efter sagde man på statsbanegården farvel til de populare franske soldater. De havde optrådt venligt og korrekt, og vi havde haft mange festlige timer $i$ deres selskab. Ganske naturligt samledes de danske borgeres taknemmelighed over Frankrigs andel $i$ genforeningsmuligheden om landets unge repræsentanter. Nu lød der dansk kommando på kaserneområdet, og de danske soldater prægede bybilledet.

Seminariets øvelsesskole.

I påskeferien skete for mig personligt noget afgørende. Under besøg i mit hjem i Vejen blev jeg ringet op af seminarieforstander Skat Rørdam, som spurgte, om jeg var bundet til privatskolen i 


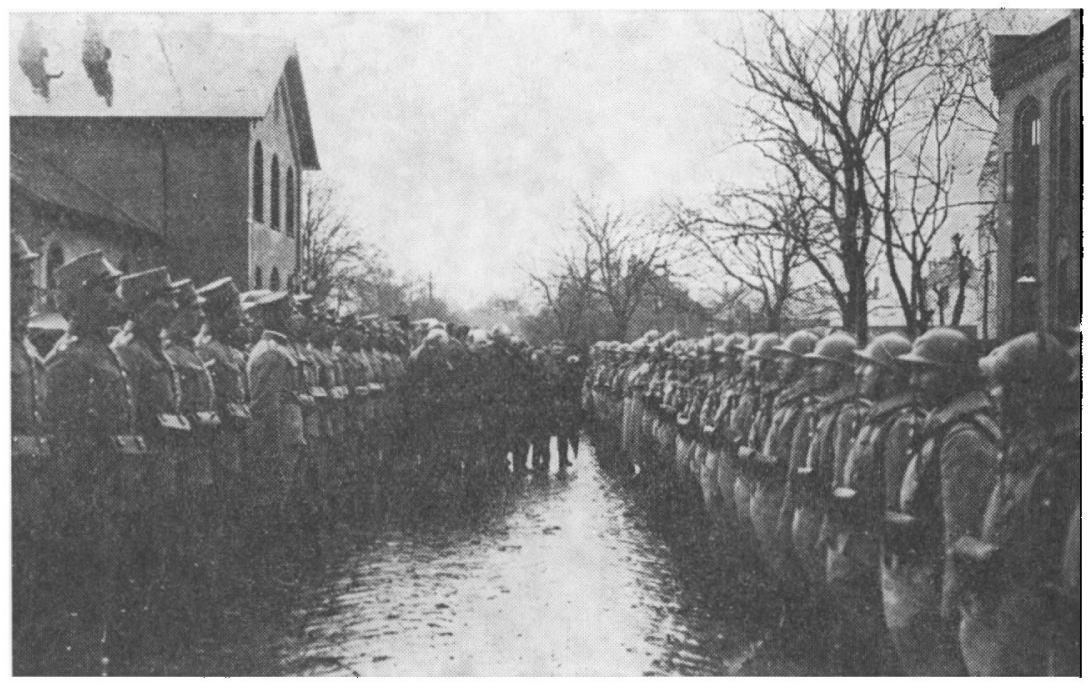

De danske soldater tager a/sked med alpejagerne pä banegården.

Haderslev. $\mathrm{Da}$ jeg svarede, at det var en forudsætning, at skolen skulle opløses ved genforeningen og eleverne fordeles i de offentlige skoler, fortalte Rørdam, at han var udset til forstander for Haderslev statsseminarium, og at øvelsesskolen skulle åbnes med danske elever efter påskeferien. Hvis jeg kunne frigøre mig, kunne jeg ansættes som midlertidig lærer indtil sommerferien. Derefter ville spørgsmålet om fast ansættelse blive taget op. Tanken om at få Rørdam som chef og udsigten til at blive lærer ved noget så interessant som en øvelsesskole var så betagende, at jeg straks satte mig på cyklen med kurs mod Haderslev. Her forelagde jeg sagen, som den var, og bestyrelsens frisind og forståelse løste mig straks fra mine forpligtelser. Der var blot én ting, man ikke rigtig forstod: at jeg foretrak øvelsesskolen fremfor de kommunale skoler! Jeg søgte da at forklare, at en dansk ovelsesskole virkede under helt andre forudsætninger end en tysk. Den ville blive en mønsterskole, erklærede jeg frimodigt. At den blev en særdeles efterspurgt skole, viste sig da også. $\mathrm{Da}$ jeg en årrække senere blev skolens leder, kom jeg ud for, at forxldre mødte op for at få børn på 6-7 måneder indskrevet! Så mente de, at pladsen måtte være sikret! Jeg spurgte 


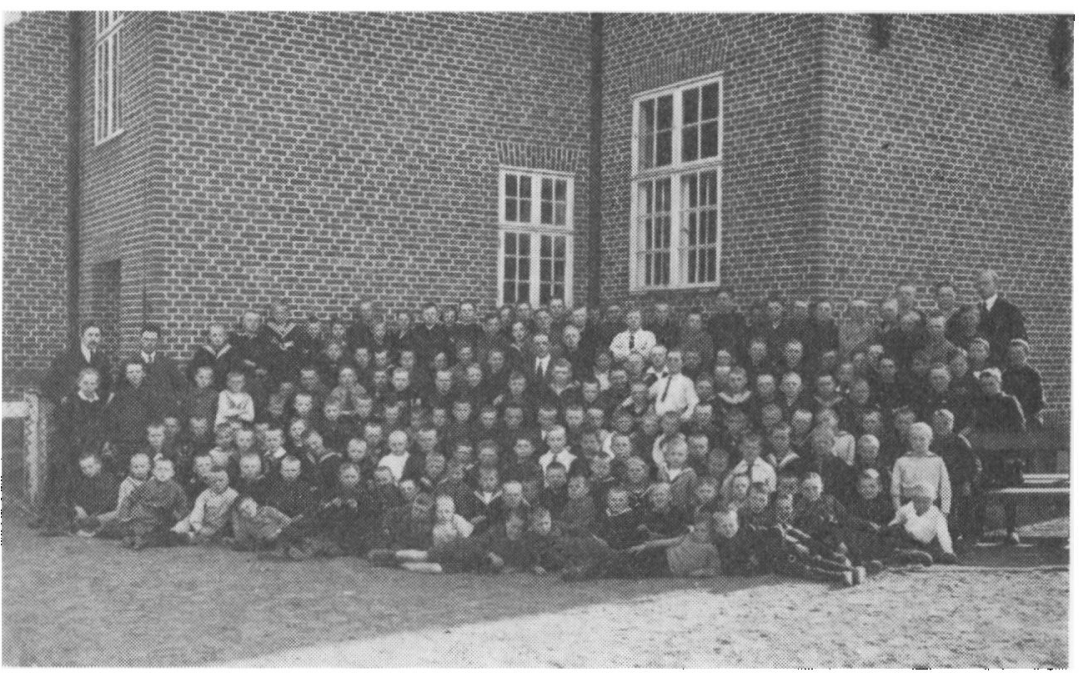

Seminarieskolen som dansk skole $i$ foråret 1920.

dog ikke som frk. Zahle i København, om de regnede med at få flere børn!

Øvelsesskolens elever overflyttedes fra den tyske Frederiksskole på grundlag af forældreønsker, men vi fire unge lærere, som tog imod, så med undren store drengeskarer strømme op ad trappen. Børnenes ønsker og nysgerrighed havde nok taget luven fra forxldreønskerne, mente vi. Sammen med rektor Carstensen, Frederiksskolens leder og nu beskikket som formidler af forholdet mellem de to skoler, fik vi flokken reguleret efter lidt klarere nationale linjer. Jeg husker kun et enkelt tilfæxlde af efterregulering: Gustav vakte forargelse ved at bære tysk emblem! Jeg snakkede med Gustav og afsagde så den salomoniske dom, at Gustav, når han holdt så meget af det emblem, hellere måtte bære det på sin gamle skole. Det fandt Gustav helt $\mathrm{i}$ orden, og den nationale strid lagde sig.

Ca. 200 børn i fire klasser gav en betydelig klassekvotient. Hertil kom, at elevernes standpunkt var særdeles varieret. Som dansklærer i ældste klasse delte jeg dem i fire grupper. En øvede sig på "de runde « bogstaver, en anden magtede afskrivning, en tredje diktat, og de dygtigste skrev genfortalling. Lxreren fik ikke lejlighed til at kede sig! Situationen i skolestuen var vel egentlig et 


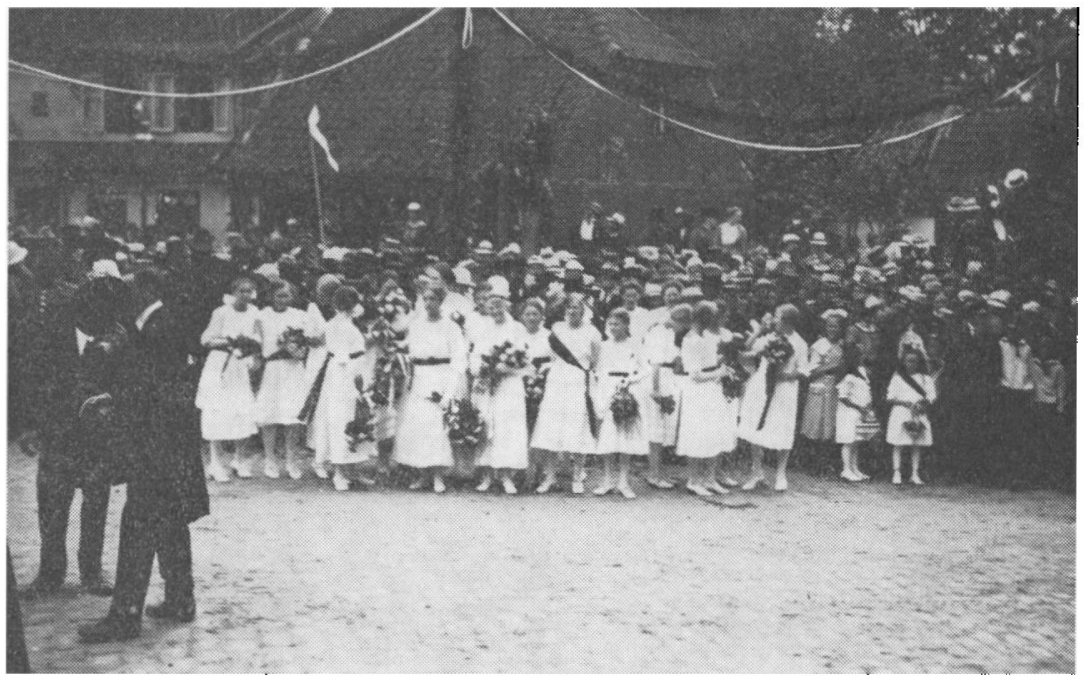

Man venter på kongen.

billede på den tilpasningsproces, der var i fuld gang i landsdelen. Efter en gennemgribende reparation åbnedes seminariet 10. september og ovelsesskolen 14. september som danske statsinstitutioner.

\section{Kongen kommer.}

Jeg har kaldt afstemningsdagen for den største og mest spændende. Det fastholder jeg, men tilføjer, at kong Christians ridt over grænsen på den hvide hest var det mest betagende. Jeg overværede ikke denne begivenhed. Det varetog min tilkommende hustru, men det anede jeg ikke noget om dengang. Øvelsesskolens elever og lærere havde fået anvist plads i Nørregade fra æresporten og sydpå. Her så vi byens modtagelse af de kongelige, og her hilste vi med hurra og flagviften. $\mathrm{Nu}$ var det hele officielt. Landsfaderen tog landsdelen i besiddelse! Frænder nordfra mødtes med sønderjyder på Dybbøl. Grev Schack udtalte de berømte ord: "Vi skal være dig gode og trofaste sønner og døtre, Danmark, det lover vi dig i dag det giver vi dig håndslag på, kong Christian!« Kongen svarede: "Indtag eders sæde blandt os, hvor eders plads så længe stod tom, og byg i fæellesskab med os Danmarks fremtid. Gud signe Danmark! Gud signe eder! 


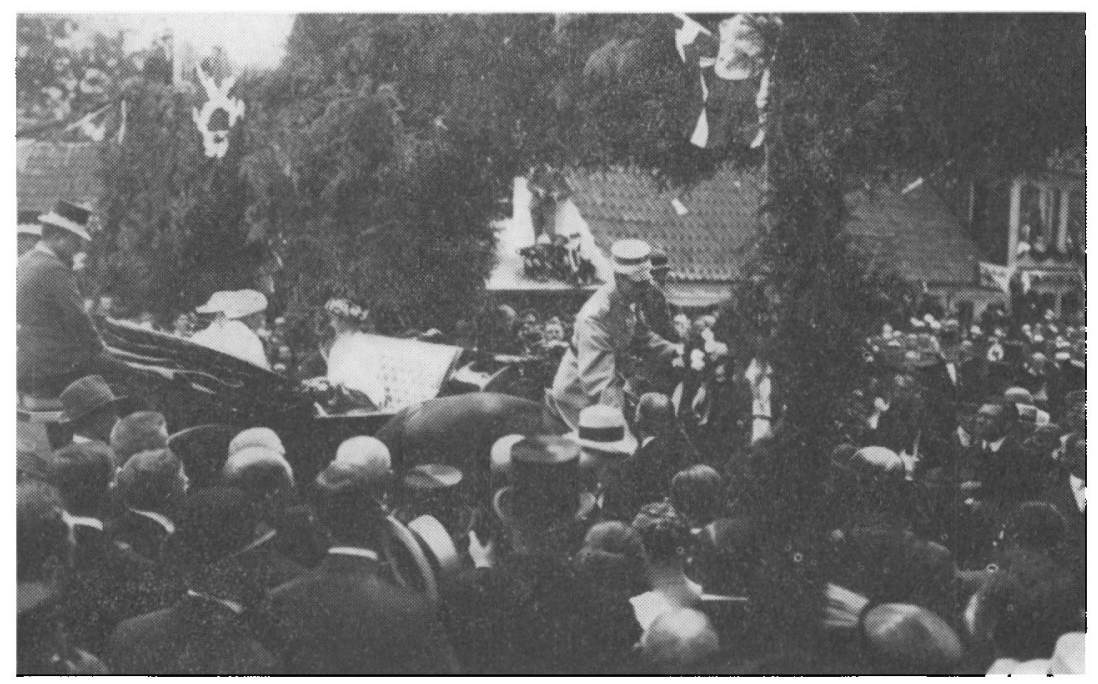

Kongen rider under aresporten ved Gammelting.

Statsminister Neergaard lovede på regeringens, »ja, jeg tor sige på hele det danske folks vegne «, at de danske syd for den nye grænse ikke skulle blive glemt.

Et for mig betydningsfuldt træk må tilføjes. Efter Dybbølmødet besøgte kongen Skibelund krat, hvor en genforeningssten skulle supplere Magnusstenen og Modersmålet. Jeg blev klar over, at kongen $\mathrm{i}$ bil ville passere Kongebroen over Kongeåen og pilede $\mathrm{i}$ fuldt løb gennem krattet, ned over marker og enge, og så da også på nogenlunde nært hold kongen passere den å, som fra mine tidligste år stod for mig med al sin mystik: grænsen! Nu slettedes denne grænse for mine øjne!

Så er blot at tilføje glæden over den gyldne arbejdstid, som fulgte. En sådan oplagthed og fxlles arbejdsglæde kan kun opleves $i$ en tid, hvor en hel befolkning har oplevet det helt store: fred og opfyldelse af slægtleds håb og drøm: genforening med moderlandet.

Som digteren sagde:

Det var en skøn begejstrings tid, hvis minde er os blevet.

Lyksalig den, som med sit land en sådan tid har levet. 


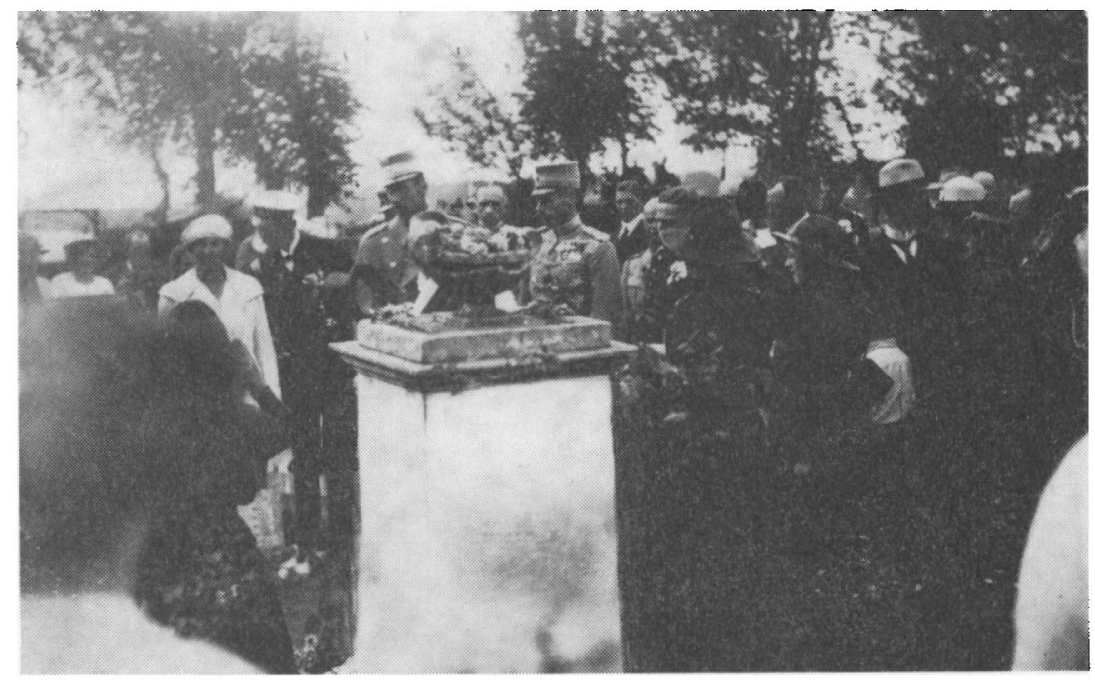

Kongefamilien ved Hiort-Lorenzens grav på Klosterkirkegården.

$\mathrm{Ja}$, således oplevede jeg for 50 år siden i min ungdom den mærkelige, den spændende, den lykkelige tid, da slægtleds håb om genforening gik $\mathrm{i}$ opfyldelse. En lykke var det, at de "fem onde år « ikke skilte det sammenføjede, men tværtimod styrkede sammenholdet, og med tilfredshed må det siges, at løftet til de dansksindede sydslesvigere: "I skal ikke blive glemt« stadig står fuldttonende ved magt.

Ovenstående fremstilling bygger $\mathrm{på} \mathrm{mine} \mathrm{optegnelser} \mathrm{fra} \mathrm{den} \mathrm{bevægede} \mathrm{vinter}$ samt på breve, som mine forældre opbevarede.

Herudover har jeg skrevet efter hukommelsen, i nogen grad med støtte i samtidens sonderjyske dagblade, som Haderslev Centralbibliotek venligst stillede til min rådighed. Overbibliotekaren er i ovrigt gammel elev fra privatskolen!

Angående tonen har jeg holdt mig op ad den, som går igennem notaterne, altså en optaget ung mands umiddelbare reaktioner, og - som jeg bemærker i fremstillingen - jeg tilstræber naturligvis ikke at skrive historie for at udrede de begivenheder, der så ofte og på så mange måder er gennemskrevet tidligere.

P. E. 